\title{
The Point of Spinifex: Aboriginal uses of spinifex grasses in Australia
}

Heidi T. Pitman and Lynley A. Wallis

\section{Research}

\begin{abstract}
For thousands of years spinifex grasses were utilized by Indigenous Australians, most commonly for the production of resin that was then used as a hafting adhesive. While varying levels of knowledge about this particular use are retained in Indigenous communities, museum collections serve as a valuable repository of little known information about a multitude of other uses of spinifex including ornamental, medicinal, structural and ceremonial functions. In this paper we describe the range of uses of spinifex, based on examinations of objects and photographs held in various museum collections, coupled with reviews of the ethnographic and ethnohistoric literature. This study (1) brings together disparate sources of knowledge about Indigenous uses of spinifex that are not well known among the scientific community and (2) demonstrates the value of museum collections for Indigenous communities seeking to 'reconnect' with aspects of socalled 'lost traditional culture'.
\end{abstract}

\section{Introduction}

'Spinifex' (also known as 'porcupine' and 'hummock' grass) is the generic term used to describe approximately 64 species of perennial evergreen grasses (Poaceae family) within the genus Triodia R.Br. (Jacobs 2004, Lazarides 1997). Spinifex grasses are endemic to Australia and common in the arid and semi-arid regions where they are estimated to collectively cover more than $27 \%$ of the continent (Griffin 1984, Latz 2007; see Figure 1). In fact, their widespread distribution in arid Australia led to the Pila Nguru of the Great Victorian Desert becoming commonly known by explorers, ethnographers and among themselves as the 'Spinifex People' (Berndt \& Berndt 1945, Cane 2002). Spinifex grasses characteristically produce highly resilient leaves that are tightly rolled and sharp tipped, and well suited to conditions of limited rain- fall and drought where they can survive in a state of dormancy until favorable conditions return.

Spinifex species are usually divided into two informal groups based on their different growth forms, distributions and physiology. The so-called 'hard' species (which include, among others, Triodia basedowii E.Pritz., Triodia irritans R.Br., Triodia longiceps J.M.Black and Triodia wiseana C.A.Gardner) have closely packed, rigid leaves which are almost impossible to touch, while 'soft' species (which include, among others, Triodia bynoei (C.E.Hubb.) Lazarides, Triodia helmsii (C.E.Hubb.) Lazarides, Triodia microstachya R.Br. and Triodia pungens R.Br.) have relatively loosely arranged, less rigid leaves that can be comparatively more easily handled. Soft species tend to be more common in the northern half of the continent where they form a more or less continuous cover, rather than the discrete, rounded hummock habit of the hard species (Moore 2005:210; see Figure 1). The primary difference between the soft and hard spinifex groups relates to their ability to produce resin. As detailed by Burbidge (1946),

\section{Correspondence}

Heidi T. Pitman, Department of Archaeology, Flinders University, Adelaide, South Australia 5001, AUSTRALIA.

heidi.pitman@uq.edu.au

Lynley A. Wallis, Aboriginal Environments Research Centre, University of Queensland, St Lucia, Queensland 4072,

AUSTRALIA.

lynley.wallis@wallisheritageconsulting.com.au

Ethnobotany Research \& Applications 10:109-131 (2012)

Published: April 12, 2012 

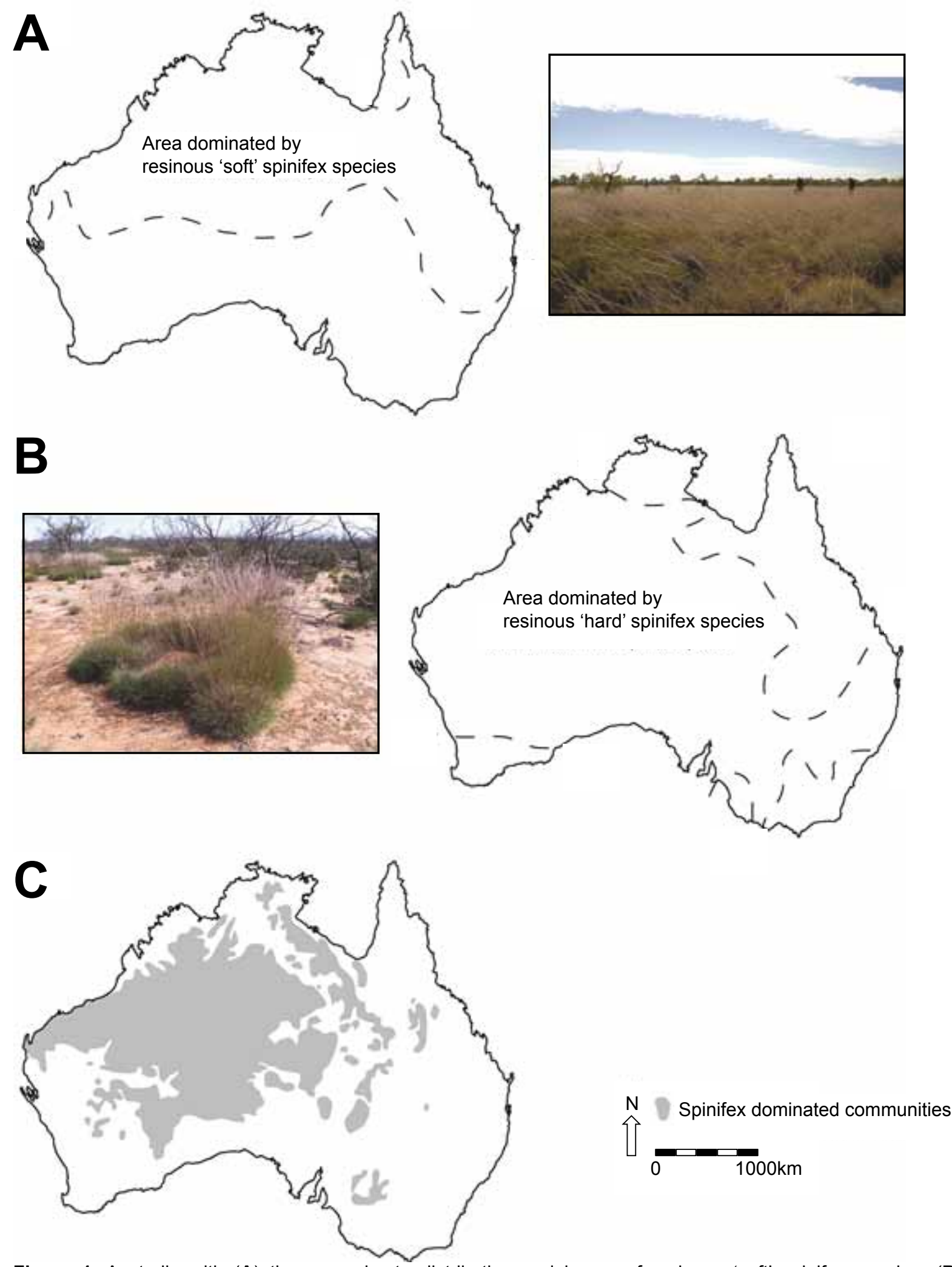

Figure 1. Australia with (A) the approximate distribution and image of resinous 'soft' spinifex species; (B) the approximate distribution and photo of non-resinous 'hard' spinifex species; and (C) the approximate distribution of spinifex dominated communities (after Griffith 1984, Latz 2007, Pitman 2010). 


\section{Pitman \& Wallis - The Point of Spinifex: Aboriginal uses of spinifex grasses in Australia}

the leaf epidermis of soft species contain specialized resin producing cells while hard spinifex species do not contain such cells and therefore are non-resinous.

To date there have been a limited number of studies investigating Indigenous uses of spinifex. Sheridan (1979) explored the relationship between spinifex resin and tula adzes (a specialized woodworking tool common to arid Australia), summarizing ethnographic accounts about resin production. While an excellent piece of research, Sheridan's thesis remains unpublished and not widely available. Binford (1984) presented research conducted with Alyawara men in Central Australia (east of the Davenport Range) on the process of resin production, providing a valuable first-hand account of the techniques involved and critical discussion of the limitations of such ethnographic research. One of the most widely recognized experts with respect to the ecology of spinifex is Latz (1995, 2007), who has undertaken extensive research in Central Australia investigating fire and the role of spinifex within the desert environment. Likewise, Clarke (2007) has also written on the role of spinifex fires in Central Australia, as well as generally on the production and uses of spinifex resin. In particularly focused studies, Kelleher and Memmott (1997) and Memmott and Go-Sam (2007) carried out systematic reviews of the role of spinifex in architecture, demonstrating its widespread use for the cladding of timber framed structures and creating windbreaks in Central Australia by Aboriginal groups, as well as in the Kimberley (northwestern Australia) by non-Indigenous settlers. Recognition of the architectural value of spinifex led to the initiation of an Australian Research Council (ARC) funded project (DP0877161) led by Prof. Paul Memmott exploring the potential of spinifex for use as a sustainable building material in remote Australia (hereafter the "ARC Spinifex Project"). Despite the value of the aforementioned studies, they have either been relatively limited geographically and/or typically focus on a restricted aspect of spinifex use (e.g., resin for hafting) to the exclusion of other applications.

While varying levels of knowledge about spinifex use continues to be held by some members of Indigenous communities, as a result of European colonization and the irrevocable alteration it caused to traditional lifeways of Aboriginal Australians, such knowledge greatly declined in the nineteenth and twentieth centuries (Clarke 2007). A great deal more information exists in the ethnographic and ethnohistoric literature, and via objects held in museum collections, in spite of the inherent biases of such sources. For instance, many ethnographic records are Eurocentric and androcentric in nature (Belk \& Wallendorf 1994, Conkey \& Gero 1991, Levy 2007, McGrath 1990, Weedman 2007); the absence of female perspectives in many accounts of Indigenous Australian lifeways has been noted by prominent female anthropologists (e.g., Bell 1983, Kaberry 1939). Likewise, museum collections are widely acknowledged as being highly selective, sampled only from specific temporal and spatial contexts and therefore not fully representative (e.g., Cooper 1989, Edwards \& Stewart 1980, Griffiths 1996, Jones 1996, Satterthwait 2008). They reflect the gender and ethnic background of collectors as well as internal and external collecting practices and policies, and also the response of Indigenous people to these circumstances (Peterson et al. 2008:2).

The timing and the motivation behind collection practices would have had significant impacts on the collection and documentation of certain spinifex technologies and related material culture items; thus it is likely that only a sample of the uses of spinifex were ever observed and/ or recorded, and to have made their way into museum collections. Nevertheless, such assemblages represent valuable sources of knowledge that might otherwise be considered 'lost'. In this paper we bring together the widely dispersed ethnographic, ethnohistoric, ethnobotanical, anthropological and archaeological literature and museum collections to present a comprehensive assessment of the range of spinifex uses by Aboriginal people.

\section{Methods}

Database and physical searches were made of the collections held by the South Australia Museum (SAM), Melbourne Museum (MM), Queensland Museum (QM) and Western Australia Museum (WAM). In addition, on-line databases for the American Museum of Natural History $(\mathrm{AMNH})$, British Museum (BM), Berndt Museum (BeM), Cambridge Museum of Archaeology and Anthropology (CMAA), National Museum of Australia (NMA), Peabody Museum (PM), Pitt Rivers Museum (PRM), Royal Ethnological Museum (REM) and the Smithsonian National Museum of Natural History (SNMNH) were searched. In order to better understand processes involved in resin production, experimentation extracting resin from $T$. pungens was undertaken during August 2010 and May 2011 at the Dugalunji Camp, Camooweal, northwest Queensland. Literature survey focused on ethnographic and ethnohistoric accounts and observations located in journals, books, theses and films. Photographic archives including Picture Australia (National Library of Australia), the Australian Institute of Aboriginal and Torres Strait Islander Studies catalogue and the Ara Irititja Archive were systematically searched.

\section{Being specific: Spinifex related terminology}

Before proceeding it is worth clarifying some of the key terminology we use in this paper, as among some historical accounts we refer to there exists considerable confusion. As noted above, the term 'spinifex' is commonly used to refer to grasses within the genus Triodia (including plants formerly classified as Plectrachne Henrard; see Lazarides 1997). However, within the non-botanical literature the term has sometimes been used indiscriminately, when in fact authors mean to refer to plants from the 
genus Spinifex L. In Australia, Spinifex spp. grasses are found throughout coastal sand-dune areas, and are very different in appearance and habitat to those of Triodia spp. (Watson \& Dallwitz 1992:860-862). Further confusion is also created by the fact that Zygochloa paradoxa (R.Br.) S.T.Blake was initially classified as Spinifex paradoxa. Zygochloa paradoxa or 'sandhill cane-grass' is the single species in this genus endemic to Australia and, while it has a similar habitat to that of spinifex, it is physically quite different (Jessop et al. 2006, Watson \& Dallwitz 1992:985986).

Within this paper we use the term 'spinifex' as a common name for plant species within the genus Triodia. Additional complexity exists because it is difficult to distinguish between the different species of spinifex, especially for non-botanists, and even for specialists if fertile material is not available for examination. Furthermore, many early accounts identify the existence of only three species ( $T$. basedowii, T. irritans or T. pungens) when in fact there are many other species now known to exist.

Another terminological issue requiring clarification relates to the words used to describe the sticky substance exuded by soft spinifex species. Over the past century various authors have often interchangeably and indiscriminately used words including resin, wax, gum, adhesive and cement for this substance. Technically, a gum comprises polysaccharides and is soluble in water, insoluble in common organic solvents such as alcohol or ether, and will not soften on heating. In contrast, a resin is a hydrocarbon secretion comprising volatile and non-volatile terpenoid and/or phenolic secondary compounds that will not dissolve in water but will dissolve in organic solvents, and will soften on heating (Langenheim 2003:23-50). Like resins, waxes are also heat-sensitive substances consisting of hydrocarbons or esters of fatty acids that are insoluble in water but soluble in non-polar organic solvents. As such gums and resins are technically quite different substances, though the terms wax and resin can correctly be used interchangeably. Herein we use the term 'resin' in keeping with its technical definition, except when citing original sources which incorrectly use other terms. Spinifex resin is thermoplastic, meaning that below its glass transition temperature (about $25^{\circ} \mathrm{C}$ ) it is hard and brittle, and above that temperature it becomes soft and malleable, making it an ideal adhesive. The terms 'cement' and 'adhesive' are used in a general sense to mean a material used to bond two objects together.

\section{Results}

\section{Spinifex resin processing}

Much information is available in the ethnographic and ethnohistoric literature about the processes involved in resin production, as summarized and discussed in detail by Sheridan (1979) and Pitman (2010). For this and reasons of brevity, a detailed description of these processes is not presented again herein; rather we provide a brief summary of the pertinent aspects of this technique for those unfamiliar with it. The primary and most widely spread means of resin processing is via threshing of soft spinifex plants to remove the adhering resin in a dry, dust-like form, winnowing and yandying to remove extraneous sediment and chaff, and then gently heating the residual material until it coagulates into a viscous form that hardens upon cooling (e.g., Binford 1984, Brokensha 1975, Campbell 1963, Cleland 1966, De Graaf 1967, Gould 1970, Roth 1904, Sheridan 1979, Tindale 1965).

\section{Indigenous uses of spinifex}

Despite the many adhesive substances accessible in Australia (e.g., Aiston 1929:45, Basedow 1925:365, Brokensha 1975, Clarke 2007, Cleland 1966, Cribb \& Cribb 1982:89, Elkin 1964:39, Latz 1995, Roth 1897, 1904, Spencer \& Gillen 1904:640, Thomas 1906:54) there appears to have been a distinct preference for spinifex resin. The latter was often used preferentially even when other adhesives were available, and was widely traded (e.g., see Aiston 1929:44, Carnegie 1898:395, Chewings 1936:7, 42, Clarke 2007:120, De Graff 1967:118, McBryde 1987:264, Roth 1897:102). In addition to its critical adhesive function our assessment reveals there are many other diverse uses of spinifex, which serve to illustrate its significance as a resource in both traditional and contemporary Aboriginal contexts. For ease of discussion we have grouped these uses into 11 main categories:

1. Plants for cladding for shelters [given the already substantive reviews of this category by Memmott \& Go-Sam (2007) and Kelleher \& Memmott (1997) this is not discussed further herein];

2. Resin as a sealant;

3. Resin for repair purposes;

4. Resin as an adhesive;

5. Resin as a malleable substance used for the crafting of beads, figurines, vessels and other objects;

6. Stems, seed stalks, leaves and stolons for basketry;

7. Fiber manufacture for string and cordage used in nets and bags;

8. Plants, resin and associated ant nests for medicinal purposes;

9. Seeds and internodes as a food source;

10. The production of fire for light, heat, communication and hunting; and,

11. Other miscellaneous uses including in games, for minimizing water loss in water carriers, wrapping objects, shoring wells, paper making and road making.

Based on our studies, we are confident that the above categories incorporate the majority of Aboriginal uses of spinifex, however, do not discount the possibility of further research, particularly any undertaken with knowledgeable Indigenous Elders, revealing additional categories of uses. 


\section{Pitman \& Wallis - The Point of Spinifex: Aboriginal uses of spinifex grasses in Australia}

\section{Resin as a sealant}

The waterproofing qualities of spinifex resin mean that, unlike gum adhesives, such as those derived from wattles (Acacia spp.) and beefwood (Grevillea striata R.Br.), it is also an effective sealant. Museum collections provide the best indication of this, as this use is rarely mentioned in written accounts. For example, the British Museum holds a bark water carrying vessel made by the Worora in the Kimberley (northwest Australia) caulked with "spinifex wax" (Oc1953,03.6). Numerous other vessels with waterproof linings appear in museum collections, although the specific material of the lining is rarely defined (e.g., CMAA E 1908.529). Visually many adhesives share similar physical characteristics, a situation further complicated when another material, such as ochre, has been used to coat them (as is common). As yet there is no quick and simple chemical test available to distinguish between adhesives (though efforts are being exerted to this end, see for example Blee et al. 2010 and Bowden \& Reynolds 1982). Nevertheless, as spinifex resin is waterproof and most other adhesives are not, it is not unreasonable to assume that the former was used preferentially when waterproofing was desired.

\section{Resin for repair purposes}

Spinifex resin was also routinely used for plugging small holes and repairing cracks in wooden and other objects (e.g., Brokensha 1975:64, Dunlop 1966, Goddard \& Kalotas 1988:14, Gould 1970:37-38, Schulze 1891:13, 288, Thomson 1964:Plate xxxix, Wightman et al. 1991:27). Museum collections indicate that repairs to wooden objects using spinifex resin were common, including coolamons, spears and shields (e.g., MM X98714, SAM A62362, BeM 3470.00D; see Figure 2) though, as with resin sealants, being confident the repair material is spinifex resin is oftentimes difficult. There are also suggestions that such use of resin could be preventative rather than curative, as a wooden bowl in the Berndt Museum (BeM 3168.00 ) is accompanied by a note stating that spinifex gum was often placed at the ends of wooden dishes in Arnhem Land (Northern Territory) to prevent splitting [emphasis our own].

\section{Resin as an adhesive}

As noted, the most common use of spinifex resin was as an adhesive for joining materials together to form com-

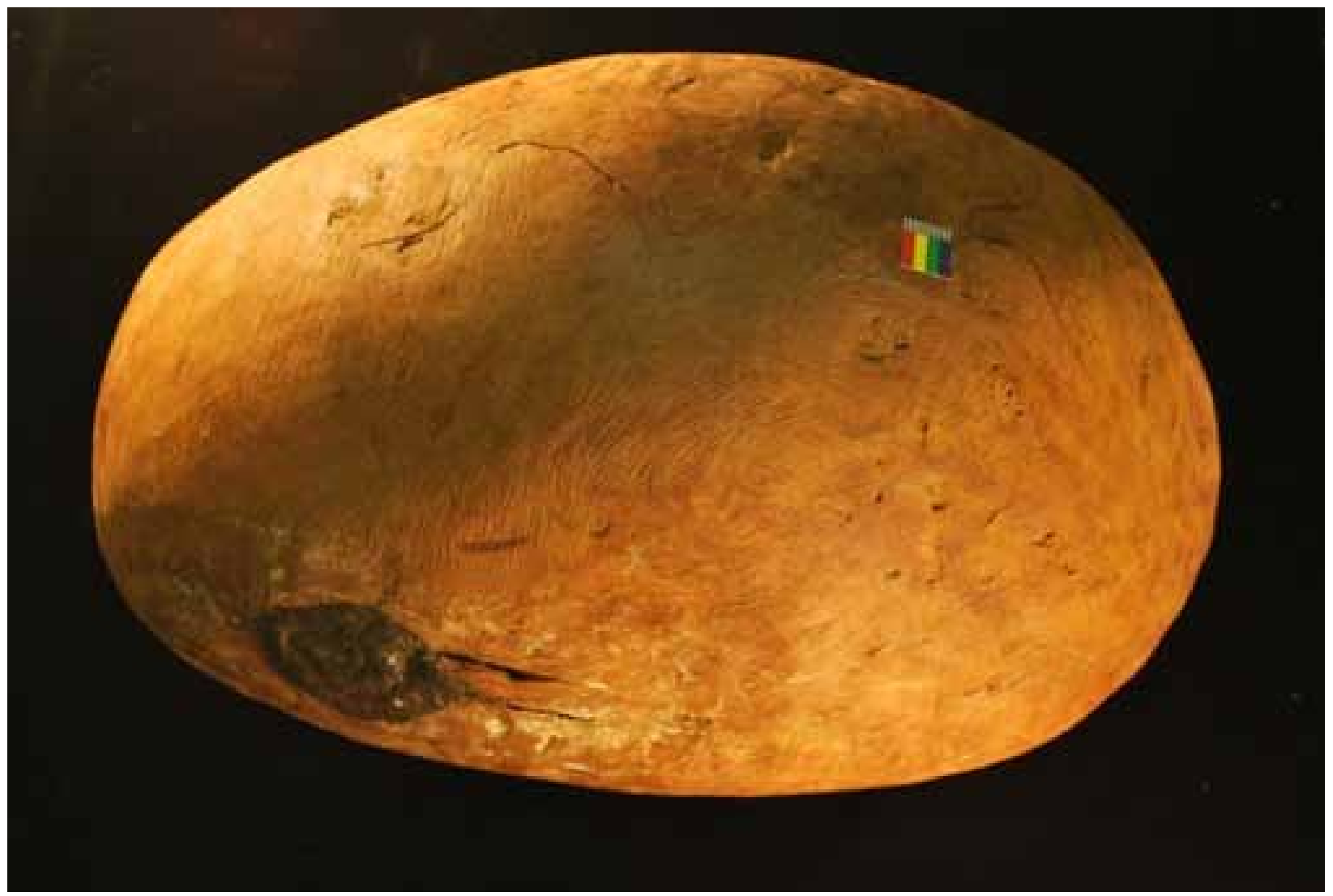

Figure 2. Wooden coolamon collected in 1971 by Robert Edwards from Ernabella Mission, Australia, showing spinifex resin repair. Currently held in the South Australian Museum collection (A62362). [Photographer: Heidi Pitman] 
posite objects. The range of such composite objects is extensive, and for the ease of discussion we have separated them into three main groups: (a) tools and weaponry; (b) items of personal adornment; and (c) items involved in sorcery.

\section{Tools and weaponry}

Adhesive-based hafting of tools and weapons offers several benefits over lashing, including the more efficient use of raw materials (Akerman 1978:489). The use of spinifex resin has been recorded at length throughout Australia for the hafting of:

- $\quad$ stone points to shafts or wooden handles to form spears and adzes, the latter including on the end of spear-throwers (e.g., Aiston 1929, Brokensha 1975:39, 45, Carnegie 1898:339-340, Chewings 1936:7, De Graff 1967:118, Elkin 1964:39, Gould 1970:37-38, Greenway 1972:194, 204, Long 1971:269, Noone 1949:111-113, Roth 1897:146-147, Spencer 1896:71, Spencer \& Gillen 1899:575, 581583, 638-640, 676-677, 1904:636-637, 667, Thomas 1906:49) and in one rare instance a wooden fighting club (Brokensha 1975:62);

- ground-edge stone axes into wooden handles (e.g., Basedow 1925:363, Carnegie 1898:342, Spencer \& Gillen 1899:590, 593). Roth (1897:151) observed that the resin is worked into the haft with the fingers

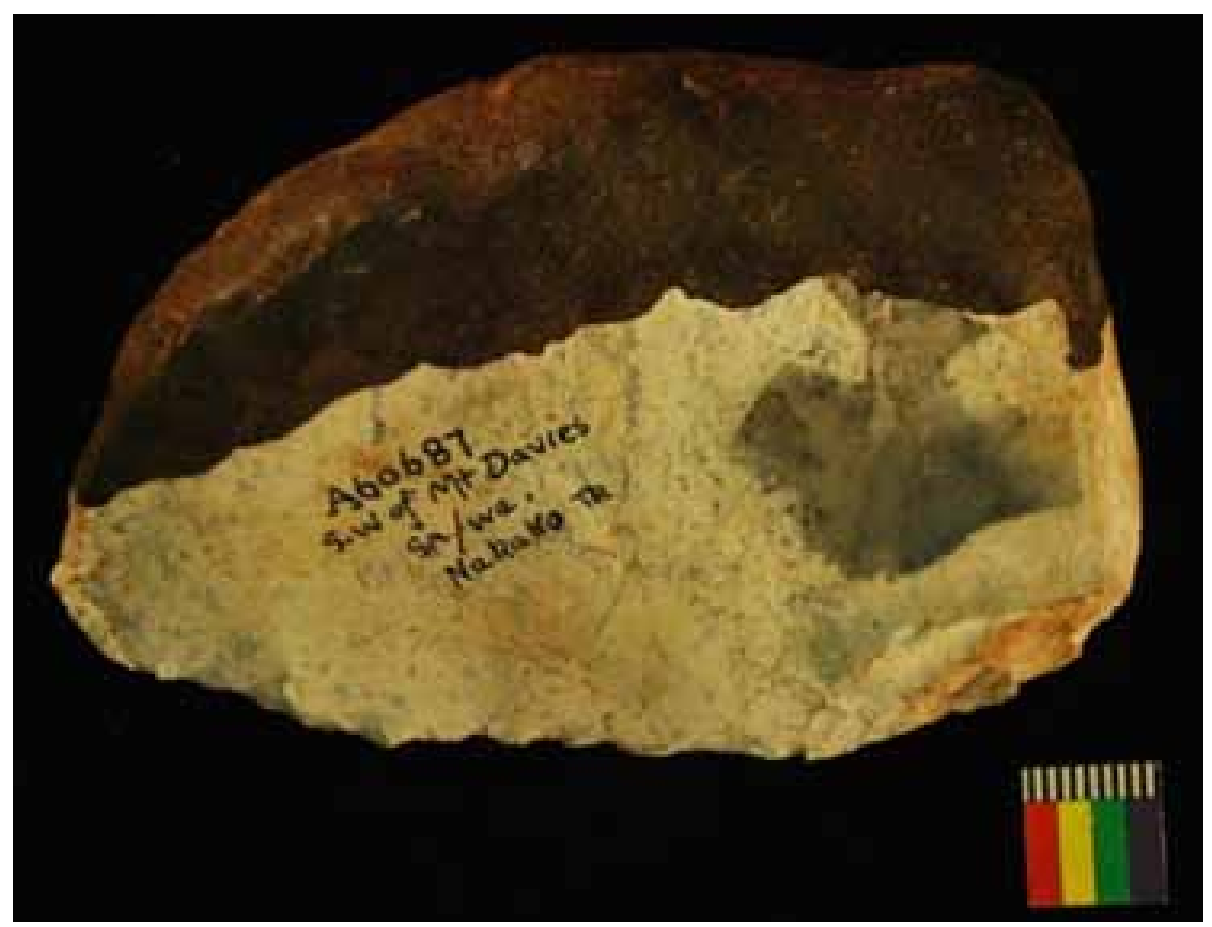

Figure 3. Stone blade with spinifex resin to facilitate handling collected by Norman Tindale from Mount Davies in South Australia in 1970. Currently held in the South Australian Museum collection (A60687). [Photographer: Heidi Pitman] to fill up any gaps which may remain between the handle and axe head to improve performance;

- wooden handled stone knives (e.g., Basedow 1925:364, Roth 1897:151, Spencer \& Gillen 1904:644-652); and,

- two-piece bone or wooden fish hooks, joined and attached to a line with resin (Spencer \& Gillen 1904:676-677).

Some objects incorporate resin not for hafting per se, but rather to create a handle for gripping. For example, Thomas (1906:50) described a saw-like implement with a row of stone flakes set in a resin handle, and there are multiple examples of descriptions of stone knives with resin attached to the butt end to facilitate handling (e.g., Basedow 1925:364, Noone 1949:112, Roth 1897:151, Spencer \& Gillen 1904:644-652; see Figure 3). Fighting clubs with a circle of spinifex resin close to one end to aid in grasping were made by the Kaitish and Warramunga (from northwest of the Davenport Range in Central Australia) (Spencer \& Gillen 1899:602-603). Among the Wambia (from southeast of the Barkly Tableland in Central Australia) a circle of spinifex resin was also recorded as being used to affix a fur-string tassel to the end of a spearthrower, a second circle providing a firmer grip for the user (Spencer \& Gillen 1899:581). Likewise, the Berndt Museum includes a wooden message stick with spinifex resin moulded around one end from the Western Desert (BeM 1727.00); a similar object is held by the National Museum of Australia (NMA 1985.0101.0310).

Museum collections in Australia and overseas abound with examples of the aforementioned types of artefacts, though rarely has sufficient level of detail been recorded to be entirely certain of the adhesive used.

One final, unusual use of resin in this category was observed by Spencer and Gillen (1899:588) who described how star- or sometimes irregularly-shaped patches of resin were inserted into the wood of shields. They recorded these as having no functional use but rather as being purely for ornamentation purposes. 


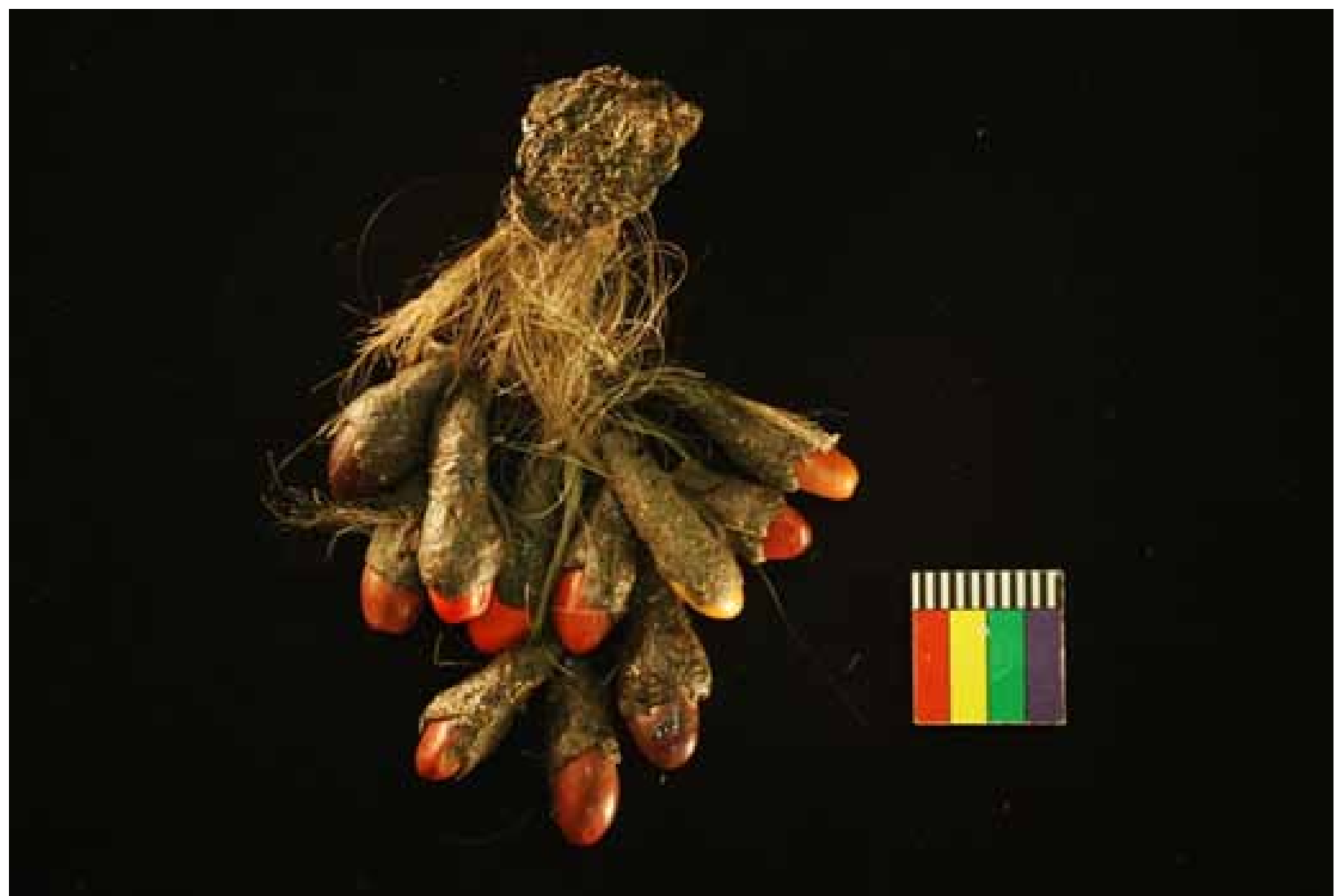

Figure 4. Personal adornment object of unknown date made from Erythrina vespertilio Benth. seeds attached to human hair using spinifex resin. Thought to be from the Dalhousie Station in the Northern Territory, Australia. Currently held in the South Australian Museum collection (A60598). [Photographer: Heidi Pitman].

\section{Personal adornment}

Beyond weapons and tools, spinifex resin was also used extensively in the manufacture of objects of personal adornment. In such items the resin was typically used either to join two different component materials or as the medium into which other items, such as seeds, were embedded. Such objects are sometimes referred to in ethnographic sources, though much less frequently than are weapons (a situation possibly explained in part by the gender bias in such literature). For example, Spencer and Gillen (1899:574) observed Kaitish and Warramunga women of Central Australia wearing, as an ornament on the forehead, a small lump of spinifex resin in which kangaroo teeth or small bright seeds were fixed. Similar ornaments are also described by Spencer and Gillen (1904:688), Roth (1897:109), Chewings (1936:40, 65) and Carnegie (1898:245), along with neckbands with inset small bone, eagle claw, teeth, shell or seed pendants (Spencer \& Gillen 1899:691, 692, 694), and arm bands with feathers or claws (Spencer \& Gillen 1899:687). Many elaborate examples of such items are present in museums, including pendants (e.g., AMNH 80.1/ 5607, NMA 1985.0060.0737, SAM A3057), armlets, hair pieces (e.g.,
BeM 3471.00D, NMA1985.0112.0141, SAM A3268), brow ornaments (e.g., PRM 1900.55.259), belts and other miscellaneous items (e.g., SAM A60598; see Figure 4). 'Pins' of wood and gum occur in the British Museum made by the Dieri (from the Strzelecki Desert in central Australia) (e.g., Oc1908, 0620.33-35), with McBryde (1987:264) noting the Dieri obtained their spinifex "from distant areas west or north of Cooper Creek" through well established trade routes as resinous species did not grow locally. One object of personal adornment found in abundance in museum collections (perhaps due to its prevalence among Aboriginal men throughout central Australia), were nose bones or pegs, which were commonly worn through the pierced nasal septum to mark the end of childhood. Usually the bone was kangaroo, but could also be bird, in which case one end of the hollow bone was filled with spinifex resin and the other ornamented with feathers (Spencer \& Gillen 1899:574; see AMNH 80.1/ 5603-5606, BeM 3173.00-3181.00).

\section{Resin for sorcery purposes}

In this third sub-category of adhesive resin uses we include composite objects related to sorcery. In these in- 
stances it appears that the resin serves a purely functional purpose, rather than being independently invested with power. Such objects are often well-described in the ethnographic literature, as well as being well-represented in museum collections (Aboriginal ritual and spiritual life having held a particular fascination for early ethnographers and anthropologists). Note we consider these items as distinct from resin related objects used for positive medicinal purposes, which are dealt with in a separate category below.

Among the most common sorcery related objects in museum collections are pointing sticks, typically comprising wooden or bone sticks with human hair attached to one end using resin (e.g., ANMH 80.1/5609, BeM 4189.00, BeM 4675.00, WAM A24071-A24075). These were reportedly used for a variety of purposes, such as described by Spencer and Gillen (1899:535-536):

"The injilla is a small bone about six inches long, at one end of which is a small lump of resin procured from the porcupine grass, and round this a few strands of human hair string are wound. It is used by a Kurdaitcha man who places it under the tongue of his victim, its special virtue when thus employed being that it renders the injured man perfectly oblivious of what has befallen him at the hands of the Kurdaitcha ... The irna is a small piece of wood perhaps as much as nine inches in length, though it may be less than this. At one end it tapers to a point and at the other is tipped with a small lump of porcupine grass resin. The stick is further ornamented with a series of notches which are apparently made with a fire-stick. The injilla or irna-both being equally effective-are charmed, that is, sung over, and thereby endowed with magic power..."

Berndt and Berndt (1943:126) suggested such artefacts were a relatively recent addition to desert sorcery, possibly being introduced from the east or northeast. Sometimes these pointing 'sticks' were stone artefacts, such as a serrated green chert flake (with human hair attached using resin), collected from the Northern Territory (BeM 3724.00).

Another sorcery object used for ill-intent is a lump of resin into which is attached rat-teeth and hair-string, also described by Spencer and Gillen (1899:540-541):

"... the name of the sun is tchintu, and the same name is also applied to an object of magic which consists of a small pear-shaped lump of porcupine-grass resin, into one end of which are affixed two incisor rat-teeth, and at the other end is attached a stout piece of hair-string about two feet in length. The string is covered with red down, and the whole is carried out of sight, wrapped up in thin pieces of bark of the paper-bark tree... This tchintu is supposed to contain the heat of the sun, and it is believed that by placing it on the tracks of an individual the latter will be seized by a violent fever which will rapidly burn him up."

Other unusual sorcery objects with spinifex resin components held in collections include a quartz crystal with spinifex resin attaching a length of human hair-string. Collected from Fitzroy Crossing in the Kimberley, this was said to be used as a "light" when dream travelling (BeM 3725.00 D). A small charm made of a "piece of skin wrapped round spinifex gum, with short string attached" was collected from Elsie Springs in the Northern Territory (PRM 1900.55.300), though no further information is available as to its exact use. Pearl shell ornaments (incorporating human hair attached with spinifex resin) originating in coastal areas and traded widely into the central desert area were recorded as being used in magic and rainmaking (e.g., BeM 3470.00 D, REM 1321-3; Akerman with Stanton 1994, Mountford \& Harvey 1938).

Another rare object perhaps more correctly identified as being used for ceremonial purposes than sorcery (but being a composite object and of similar form to those described above is included here) includes a sharpened, incised bone with human hair attached with resin (BeM 3186.00). This object, from the Docker River area of the Northern Territory, while superficially similar to a pointing stick (as described earlier) was reportedly used "to puncture veins for the collection of blood for ceremonial occasions" (BeM 3186.00 catalogue entry).

\section{Resin for the crafting of beads, figurines, vessels and other objects}

The malleability of spinifex resin makes it highly suited to manipulation into beads, figurines, vessels and other miscellaneous objects. These are distinctively different from those items of personal adornment listed above, as in these instances the resin is the primary focus of interest rather than merely being the adhesive medium. Knowledge of items crafted from resin comes almost exclusively from museum collections as written literature rarely, if ever, mentions such objects. This is possibly because of the 'uncommon' and oftentimes sacred nature of such items - the chance of them having been witnessed in use by non-Indigenous observers was probably minimal.

During the late nineteenth century Emile Clement collected from northern Western Australia several examples of spinifex resin beads (bulga), at least some of which were strung (e.g., BM Oc1898,1011.13, BM Oc1960,11.64, PRM 1898.75.64; Clement \& Schmeltz 1903). Despite systematic searches we have not yet identified any other such spinifex beads or necklaces in other collections, making these particularly interesting museum objects.

In a contemporary context (and used for non-personal decorative purposes), Indjalandji/Dhidhanu (from around 


\section{Pitman \& Wallis - The Point of Spinifex: Aboriginal uses of spinifex grasses in Australia}

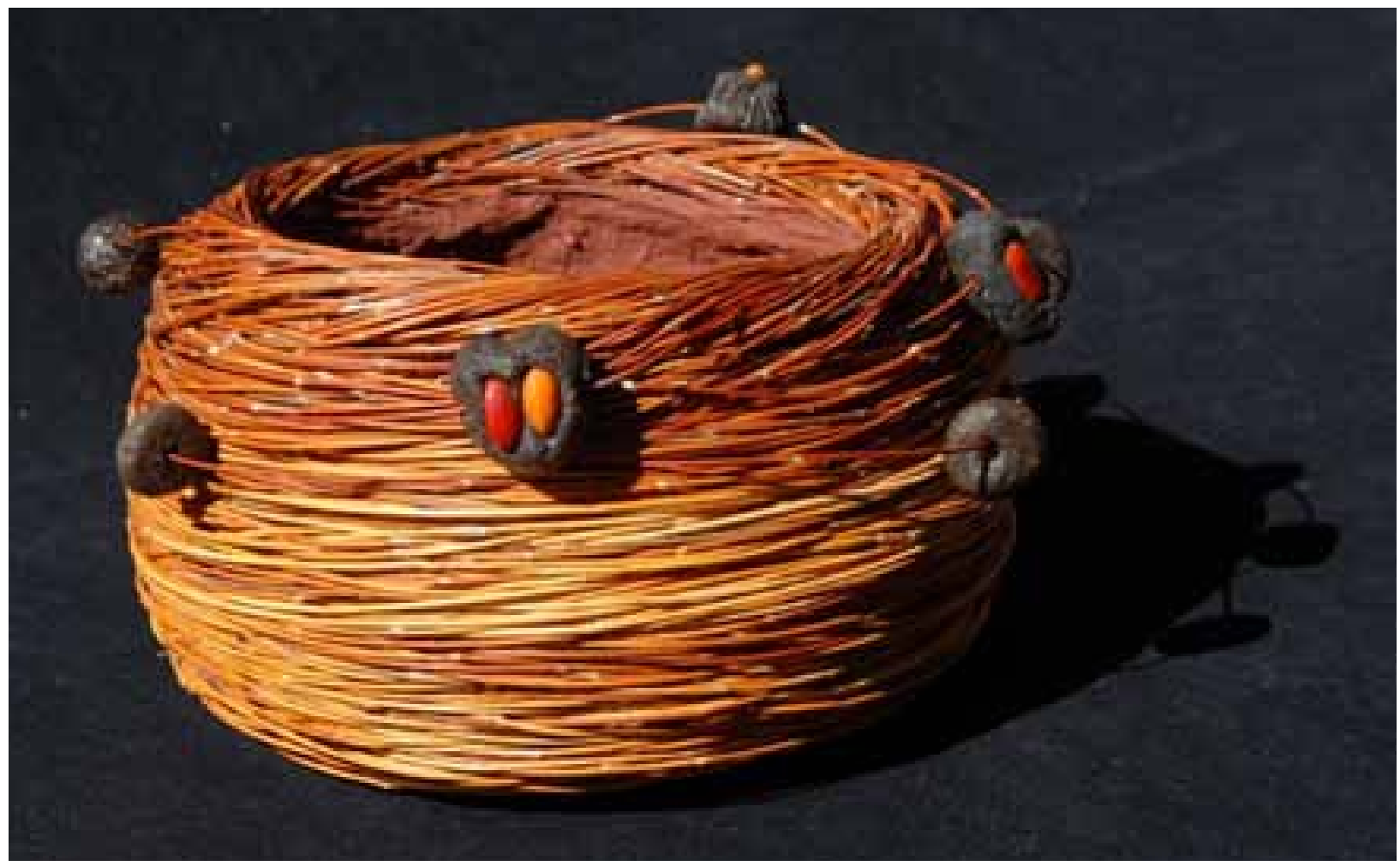

Figure 5. Contemporary basket made using spinifex stolons with ochre lining and spinifex resin beadwork with Erythrina vespertilio Benth. seeds, crafted by Shirley McNamara in northwest Queensland, Australia. [Photographer: Lynley Wallis].

Camooweal in northwest Queensland) artist Shirley McNamara has fashioned small balls of spinifex resin and incorporated them into her basketry (Figure 5). Likewise, Central Australian weaver Pantjiti Lionel incorporated spinifex resin in her raffia sculptures (NMA 2001.0018.0001, 2001.0018.0002). While the aforementioned objects are contemporary, there are some indications to suggest resin figurines may have a longer antiquity. For example, seven dog figurines crafted probably from spinifex resin, some decorated with white clay and red ochre, are held in the South Australia Museum (SAM A422-A428; Figure 6 ). These were collected from the Killalpaninna Mission area in the Lake Eyre Basin in the late nineteenth century and each represents an individual dog which belonged to particular Ancestral Beings in Lake Eyre mythology (see Jones \& Sutton 1986:13, 136-137, Nobbs 1985:17).

The use of spinifex resin objects in ceremonial contexts is further apparent in other museum objects. Churinga/tjuringa are usually inscribed wooden slabs used in male ceremonies in Central Australia (Spencer \& Gillen 1899:123). Unusually, De Graff (1967:118) described such sacred boards made from spinifex resin (up to three feet or more in height and incised with totemic designs); each participant in the ceremony contributing a portion of the resin. The size of these boards represents a considerable investment of labour in order to procure the large quantity of resin required. A small inscribed tablet, possibly made from spinifex resin is also present in the restricted section of the South Australia Museum collection (SAM A77363); however, owing to its restricted nature, it was not possible to garner any further information about it.

Spencer and Gillen (1899:545) also noted the presence of a resin component of some wooden churinga/tjuringa boards:

"Among the churinga there are certain special ones which are used for special magic purposes, the latter having an intimate relationship to the totem to which they belong. One of these is called churinga unginia and belongs to a rat totem, the animal being distinguished by the possession of very long whiskers. Unlike any other Arunta churinga with which we are acquainted, this one has a lump of resin attached to one end and is painted with alternate stripes of red and black. It is in special request by the young men, as it has a remarkable power of increasing the growth of the beard."

Another example of spinifex resin objects from a ceremonial context comprises two large, egg-shaped spinifex resin balls held in the Berndt Museum (BeM 2014.00). The written note accompanying these objects states they 


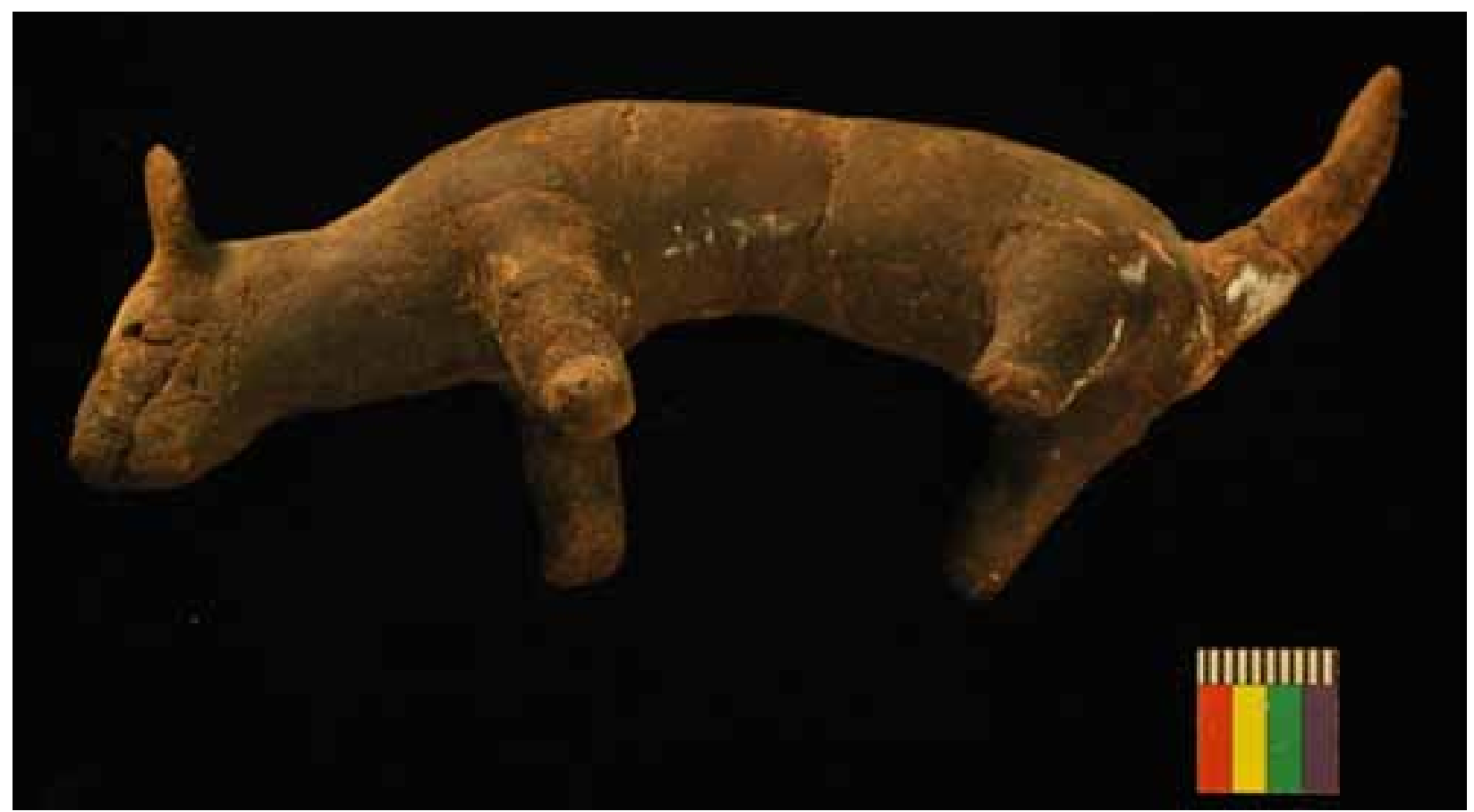

Figure 6. Figure of a dog belonging to an Ancestral Being probably crafted from spinifex resin. Collected by Reuther from the Killalpaninna Mission area in the Lake Eyre Basin, South Australia in the late nineteenth century. Currently held in the South Australian Museum (A68460). [Photographer: Heidi Pitman].

are said to represent the metamorphosed testicles of the Great Kangaroo Ancestral spirit whose creative pathway crossed through the Blood Range area of Central Australia.

Other evidence to suggest that the crafting of ceremonial objects from spinifex resin occurred traditionally comes from the Warburton Range in the Great Victoria Desert. Here in 1963 De Graaf collected five spinifex resin bowls (WAM A24230-32), used to collect blood during bandicoot totem increase ceremonies. They were accompanied by an abstract resin figurine (with legs and face indicated, but no arms) associated with the same ceremony (WAM A24233). A final sacred object associated with male ceremonies in the region also collected by De Graaf included an oval-shaped cake of spinifex resin, though little detail about its purpose was reported (WAM A24235). De Graaf also collected rings crafted from spinifex resin used in ceremonies by women, possibly relating to the desert goanna totem (WAM A24234). We have been able to find no written references to these sorts of uses of spinifex resin, and thus these museum objects represent particularly interesting finds.

\section{Basketry (traditional and contemporary)}

Woven basketry does not seem to have been commonly practiced in central Australia prior to European invasion, the traditional vessels here being wooden and bark con- tainers, and hair-string bags (Nicholls 2005:35). However, in recent decades basketry has become a commonly practiced craft within these regions and women now commonly make baskets and sculptures from materials including spinifex (e.g., BeM 9536.00 D; Parkes 2005). Likewise, Indjalandji/Dhidhanu (from northwest Queensland) fiber artist Shirley MacNamara uses spinifex stolons ('runners') for her contemporary coiled basketry (Figure 5), bracelets and other objects including fascinators. Despite this, there is limited evidence that spinifex was traditionally used for weaving baskets anywhere in Australia. The only example we have located to date of such use comprises two basketry objects made from spinifex seed heads collected by Tindale in 1966 in northwest South Australia (SAM A68558, A68559; see Figure 7). Two photographs of these objects being made by Jackie Bellrock, a Nakako man (from central Australia), are present in the Ara Irititja Archive. A bundle of non-resinous Triodia sp. was also identified (SAM A42750); although its purpose is not specified in the museum catalogue, this material was possibly used for fiber-work, as it is registered adjacent to two other plant samples labelled as such.

\section{Net, bag and fiber manufacture}

Though not widely known, there is evidence that in some areas spinifex fibers were utilized traditionally for net manufacturing. The explorers Gregory and Gregory (1884:71) 


\section{Pitman \& Wallis - The Point of Spinifex: Aboriginal uses of spinifex grasses in Australia}

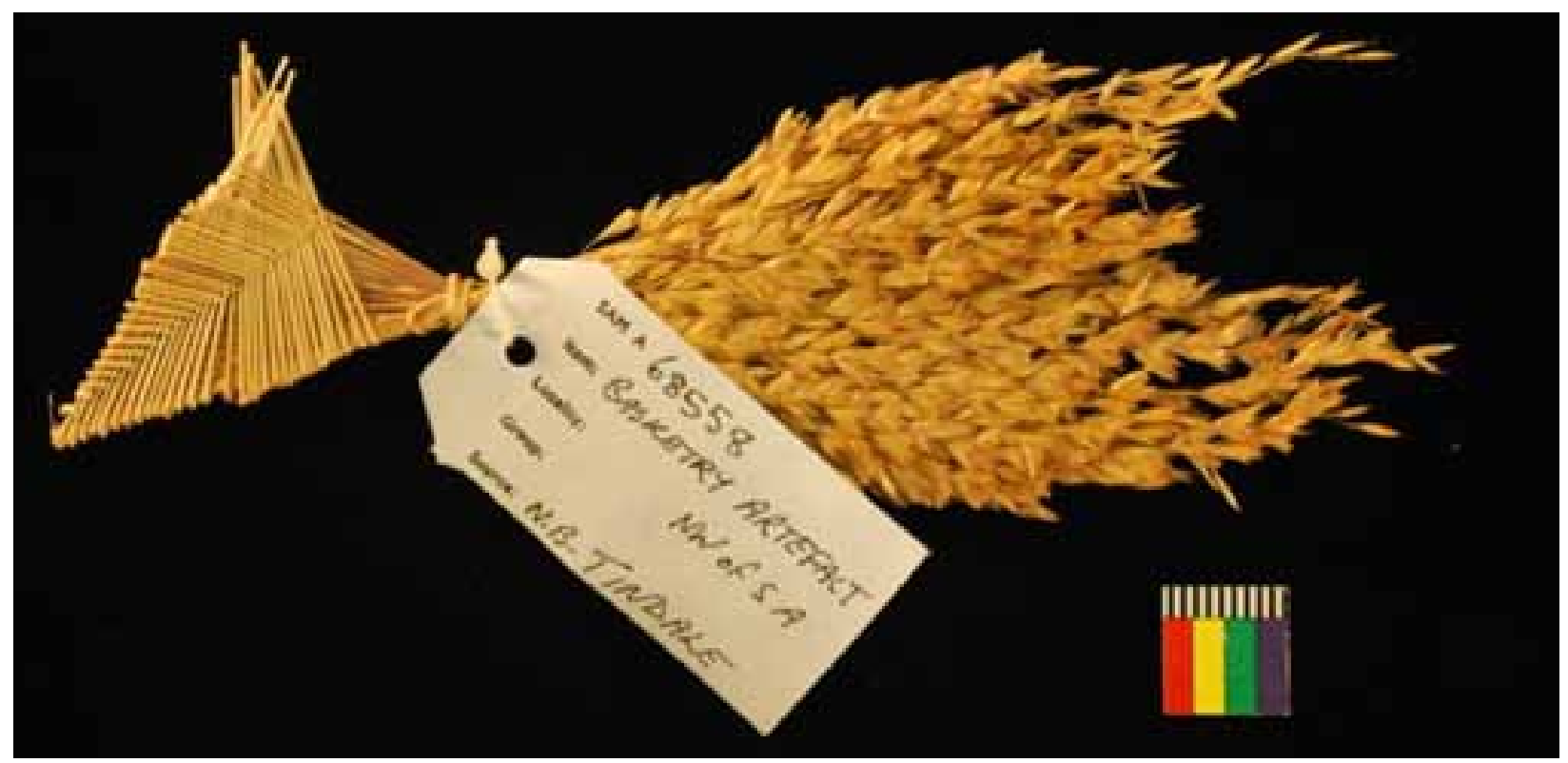

Figure 7. Basketry object made by Jackie Bellrock using spinifex seed stalks. Collected by Norman Tindale in the northwest of South Australia in 1966. Currently held in the South Australian Museum (A68558). [Photographer: Heidi Pitman].

documented such a use around the Sherlock River in north Western Australia:

"Several natives were found here, employed capturing partridges by means of nets constructed out of the leaves of the Triodia neatly twisted and netted in the same way as done by ourselves, the mesh varying from one to five inches, according to the purpose to which it is applied."

Similarly, in the early twentieth century Bates (1985:248, 250,253 ) recorded the people of north Western Australia making nets, of different sizes and meshes, from the fibrous leaves of Triodia sp. These nets were reportedly used in a variety of fishing and trapping techniques, and she also noted that spinifex fiber bags were also used for storage and transport purposes.

Although other written references to spinifex fibers are scarce, Sherlock River and Roebourne feature strongly in relation to spinifex nets (tukurra/tarurra), bags and raw material samples held in overseas museum collections collected by Clements (e.g., BM Oc1960,11.63, PM 2346-70/D1728, PRM 1898.75.7.1, REM 1321-29; see Figures 8 \& 9). Additionally, a spinifex fishing net and raw material used in its manufacture were also collected by Radcliffe-Brown from north Western Australia (CMAA E1914.70.65). In Australian museums, there are similar examples of spinifex string, bags and nets collected from Chiratta Station (near Roebourne) (e.g., WAM E08215, 00604), along with a spinifex net and two spinifex bags (WAM E00350-52) from an unspecified north Western Australia locality. The Berndt Museum contains a bag woven from sedges that contains a "net made from twine of

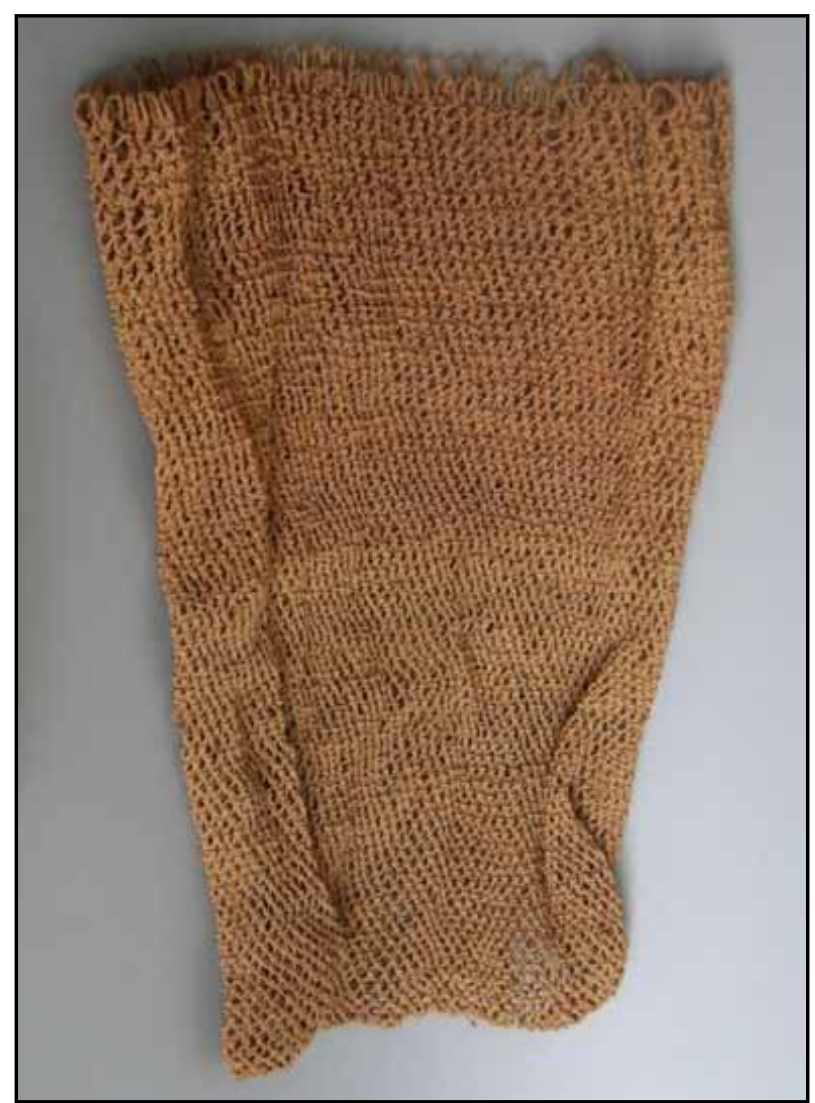

Figure 8. Bag made from spinifex fiber collected by Emile Clement from north Western Australia in the late nineteenth century, now held in the British Museum (Oc1960,11.63). [Image courtesy of the British Museum]. 


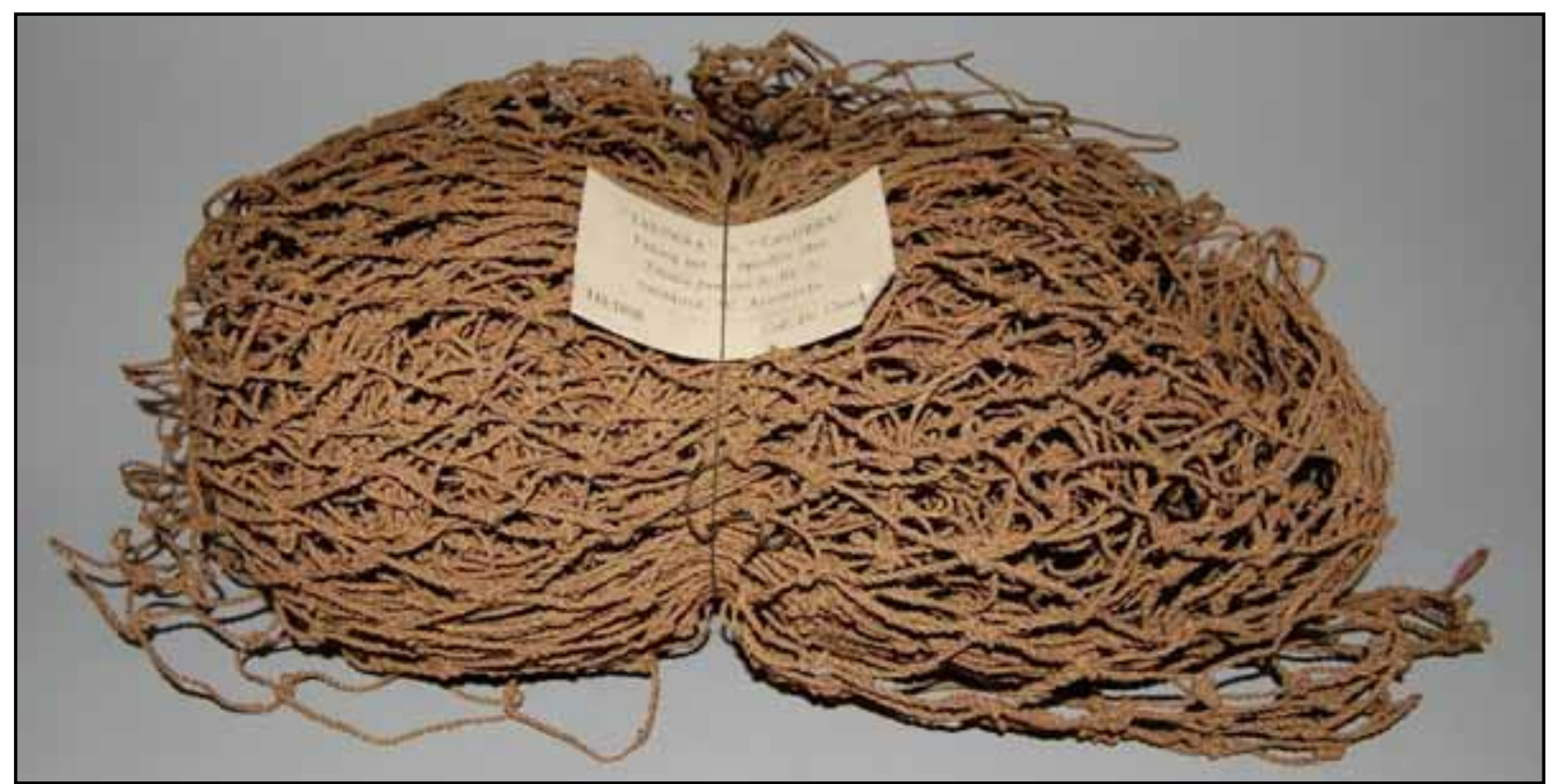

Figure 9. Net made from spinifex cord collected by Emile Clement from the Sherlock River region of north Western Australia in the late nineteenth century, now held in the British Museum (Oc1960,11.59). [Image courtesy of the British Museum].

spinifex grass" (BeM 6355.00) thought to have been collected from the Cossack area of Western Australia.

Bindon (1996:257) reported clumps of $T$. aff. wiseana being "pounded between two stones until fibrous, like cotton wool, and then spun into a string". This information was conveyed by elderly Aboriginal men who advised they had witnessed their mothers performing this task (Peter Bindon pers. comm. 2010). Of further relevance here, a grindstone from the Warburton region of Western Australia was recorded specifically as having been used for grinding spinifex leaves (CMAA 1926.591). Whether this object might have been involved in spinifex fiber production, or whether the collector misidentified its use and spinifex seeds were meant instead of leaves is unclear (though see the later section on spinifex as a food source). In this respect, a label associated with spinifex string samples in the Western Australia Museum may also be of relevance, as it specifies "spinifex beaten ready for making twine" (WAM E03261; see also WAM E03260).

An article in The Argus in 1884 identified that it was possible to make string from a spinifex ( $T$. irritans) and concluded that, though short, spinifex fibers were stronger and "better" than those of the Indian jute and were sufficiently long to be made into rope (Lockhart Morton 1884). Despite this early recognition of the potential economic value of this plant, there do not seem to have been any attempts by non-Indigenous peoples to utilize spinifex grasses for fiber production until recently. As a member of the ARC Spinifex Project team, Flutter (2009) examined the physical properties of spinifex cellulose. While further research was recommended, initial testing of the tensile strength of spinifex fibers revealed they may meet the basic criteria for medium performance composites; this research is ongoing.

As is possible with most fibrous plant species, spinifex has also been used on occasion for paper marking. The earliest report we have been able to locate of such a use is from 1887, when The Northern Territory Times and Gazette made reference to paper being made from spinifex harvested in South Australia (Anonymous 1887). During the 1990s a group of Indigenous women in Papulankutja (a township formerly known as Blackstone in the Western Desert) commenced spinifex paper manufacturing and, although no longer being undertaken, this enterprise made an important contribution to the highly successful Indigenous owned and managed artist's cooperative, Papulankutja Artists (Lottery West n.d.). More recently Tim O'Rourke of the ARC Spinifex Project has worked with paper makers to produce a serviceable textured card from spinifex fiber sourced from Camooweal (northwestern Queensland); anecdotal accounts suggest this practice is undertaken intermittently around Australia.

Spinifex plants themselves, rather than nets made from fiber, are used by Aboriginal people for fishing (Figure 10). The plants are laid across one end of a pool and then pushed through the water by people so as to herd the fish to the edge of the water where they are forced onto dry ground and collected (Flinders 1920-1936, Juluwarlu Aboriginal Corporation n.d.:17, Latz 1995:226, 293, Moses 1986). 


\section{Pitman \& Wallis - The Point of Spinifex: Aboriginal uses of spinifex grasses in Australia}

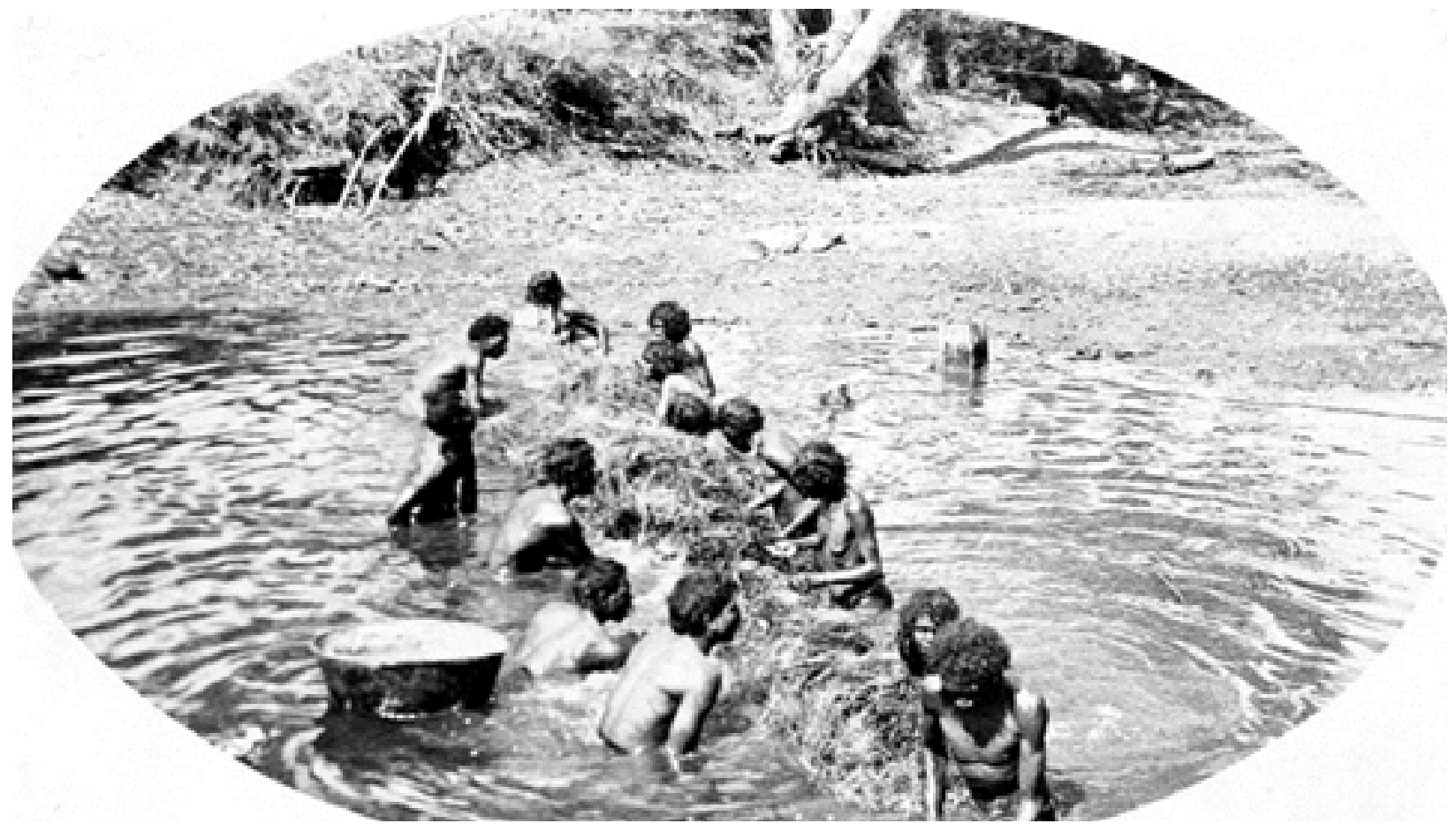

Figure 10. Aboriginal people fishing using a moveable wall of spinifex plants to herd and catch fish in a river of the Kimberley, Western Australia in the early twentieth century. [Image courtesy of the State Library of Western Australia BA1459/170].

\section{Medicinal applications}

Like the use of spinifex for fiber manufacturing, the medicinal applications of spinifex grasses are not especially well known. For example, in their wide-ranging texts on medicinal plants neither Maiden (1889), Cribb and Cribb (1988), Cribb (1985) nor Webb (1959) made mention of Triodia. However, there are several accounts which specify that spinifex grasses did have medicinal value. And while the particular species is often not stated it seems likely that the properties outlined below are common to many Triodia species.

Both Smith (1991:59) and Wightman et al. (1992:33) noted that smoke created from burning $T$. pungens foliage is used in the Northern Territory as an effective mosquito deterrent. Colin Saltmere, an Indjalandji/Dhidhanu man (from northwest Queensland) reported that the smoke from burning spinifex foliage can also be inhaled as a treatment for cold and influenza (pers. comm. 2010). A similar use is reported by Bindon (1997:197) who noted that the vapors and smoke created during the heating phase of spinifex resin production was "inhaled by those who are 'cold-sick' (i.e., suffering from some respiratory complaint)".

Another known remedy involves boiling Triodia foliage in water and using the resultant liquid as a medicinal body wash, for relief from congestion, colds and influenza or for skin orders such as itchy skin and sores (Smith 1991:5859, Wightman et al. 1991:27). Rather than being applied externally, Lowe with Pike (2009:62) also reported that a similarly produced, "unpalatable" decoction could also be drunk by the patient to relieve the symptoms of cold and influenza.

Similarly, Smith (1991:58-59) recorded a restorative and preventative role for $T$. pungens related to childbirth. The whole plant is crushed and mixed with a small amount of termite nest and water, and placed over a bed of hot coals. The resultant liquid is then drunk by both mother and newborn, and is said to help maternal recovery and encourage the good health of the child. A post-natal spinifex-smoke therapy has also been recorded (Aboriginal Communities of the Northern Territory 1993:30). Crushed termite or ant nest associated with $T$. pungens is placed in a pit of hot coals and covered to produce large amounts of smoke and vapor, among which mothers sit or lie after delivery. Similarly, babies are held over the smoke for a few minutes, a treatment repeated daily for about a week which helps stop bleeding and shrivels their umbilical cord.

Dymock (1979:45) recorded resinous ant nests being ground up and rubbed over the body as a general medicine; three samples of this material were collected from 
the Nicholson River area in the Northern Territory (SAM A77268). A similar use is described in Central Australia where Latz (1995:291-2) reported that the Warlpiri will burn or heat resinous ant-beds,

"...until black, ground into a powder and wetted and then either swallowed to cure diarrhoea or rubbed onto babies for undescribed ailments. It is also apparently used in some way to increase lactation. The acrid smoke from smouldering ant-beds is also reputed to have healing properties for sick babies, and the eggs and larvae obtained from the ant-bed are reputed to be used as a healing liniment."

Molly Nungarrayi (cited in Vaarzon-Morel 1995:15) and Bindon (1997:197) provided additional accounts of antbed being used in similar fashions to those aforementioned. The ash of burnt Triodia spp. was also reportedly rubbed on sores as a medication (Bindon 1997:205).

Other indications of the medicinal values of spinifex come from museum objects. The Pitt Rivers Museum contains two cowrie shells filled with spinifex gum [sic] collected by Clement (PRM 1924.63.11,1924.63.12). These items were recorded as having been used by medicine men for rubbing over the affected part of their patients (Clement \& Schmeltz 1903). The Royal Ethnological Museum (Leiden) also contains a medicine stick (a "lump of spinifex-gum fixed to the end of an ornamented, pointed stick from 9 inches to 18 inches long or to some bone of kangaroo or bustard") known as a mahredie corrada (REM 1207-23), also collected by Clement. The use of this medicine stick is described as such:

"On returning to his patient, he blows hard upon the sore part, in order to insert a good spirit, and rubs his mahredie corrada over the spot. ... Frequently the mahredie corrada is carried by him with the gumend for an hour or more under his arm-pit and then suddenly placed under the arm-pit of the patient, or between his legs."

This medicine stick is quite different to that described in the earlier section on sorcery, as in this instance the value lies in the resin being physically rubbed across the affliction to ease suffering, rather than being 'pointed' at the victim from a distance to cause harm. Other examples of similar medicine sticks collected by Clement can be found in the British Museum (BM Oc1896,1046, Oc1896,1044, Oc1896,1045) and the Pitt Rivers Museum (PRM 1898.75.102, 1898.75.105, 1924.63.10).

\section{Seeds and internodes as a food source}

Seed grinding is widely recognized as an important subsistence strategy of hunter-gatherers in arid Australia with a Pleistocene antiquity (e.g., Cane 1987, Fullagar \& Field 1997, Gorecki et al. 1997, Meggitt 1962, Tindale 1977), though spinifex is not commonly listed among grasses whose seeds were edible (e.g., Gould 1980, O'Connell \& Hawkes 1981, O'Connell et al. 1983). With respect to the Marujarra people of the Western Desert, Walsh (1987:60) posited that, despite the preponderance of $T$. pungens in the region, its use (and that also of $T$. basedowii) as a source of seeds was limited "possibly because of the relatively long time required to separate the seed from the chaff". Most spinifex species drop their seeds rapidly; hence there is only an extremely short time period during which they might be easily collected by people. Coupled with their small size (most seeds are $<2 \mathrm{~mm}$ in maximum dimension), this meant the majority of spinifex grass species were not well suited to utilization as a food source, despite the fact that under favorable rainfall conditions some species can produce more than 10,000 seeds per square meter (Wells 1999).

Nonetheless, spinifex seeds do appear to have been utilized occasionally during periods of stress or imminent starvation. For example, in the Great Sandy Desert, Cane (1987:431) reported that $T$. basedowii (nyanmi), T. Iongiceps (lanu lanu) and T. pungens (djinal) were a "minor" source of seeds of the Spinifex People, collected predominantly during the late wet season when other food sources were in short supply (see also Long 1971:263, 267). Tom Saville, an Injilandji [sic] man from northwest Queensland recalled people eating spinifex seeds "at times of shortage" (pers. comm. as cited in Grant \& Gorecki 1996:10). Coppin Dale, an Ngarluma man from Roebourne in Western Australia, reported that local people would gather and store spinifex seeds so they could later be ground into flour (as cited in Wright 1970:17-18). Similarly, Bindon (1996:257) reported that the seeds of $T$. aff. wiseana could "be dug out of storage chambers in the nests of certain species of ant", a suggestion also made by Coppin (Wright 1970:20).

Evidence of spinifex seeds as food sources in museum collections are relatively rare, further supporting the notion that these were not a preferred or regular food source. The only specimens we identified as such included (1) a sample of edible seeds (yukulbi) from an unidentified species of Triodia, collected from the Young Range in Western Australia (WAM A17319); (2) a sample of spinifex seeds collected in 1927 from around Cue in Western Australia (BeM 4589.00); and (3) a sample of seed collected by Radcliffe-Brown in the early twentieth century from "a species of porcupine grass or so called spinifex" (CMAA E1915.20.36A).

Beyond spinifex seeds, Latz (1995:291) indicated the Warlpiri of the Tanami Desert would eat spinifex internodes "in times of hardship, but consider them a tasteless, inferior, stopgap food" (whilst also denying any past use of the seeds for food). Cane (1987:420) also reported that a sweet excretion from the leaves of the hard spinifex $T$. longiceps could be eaten. 


\section{Pitman \& Wallis - The Point of Spinifex: Aboriginal uses of spinifex grasses in Australia}

The scant and sometimes contradictory statements about whether spinifex was or was not utilized as a food source, in times of plenty or in times of starvation, requires consideration. Certainly it is likely that different groups had cultural preferences that might account for some of the apparent contradictions reported above. We also hypothesise that, as with other time-consuming technologies such as net manufacturing, spinifex seed collection and grinding may have been discarded by many Aboriginal groups soon after European alternatives became available (see also O'Connell \&Hawkes 1981) and consequently limited traditional knowledge about the use of this particular food source has been reported in the ethnographic literature. Perhaps more importantly is the inherent nature of these types of resources. As Edwards and O'Connell (1995:772) suggested, "It is difficult to see why seeds yielding such low returns [300-1100 kcal/hr] would be added to the diet unless other, more attractive resources were unavailable" and that increasingly arid conditions would be the impetus for the addition of seeds to the diet. Nevertheless, as Pate (1986) showed, drought conditions in 1969-70 did not result in the addition of seeds to the diet of the Western Desert Ngatatjara as the adaptations of certain seed plants meant they were not available when water was scarce. This might at least in part account for the use of spinifex seeds dug from the storage chambers of ants, where presumably they are accessible for a much longer period than they would be retained on the plants themselves.

\section{The production of fire for light, heat, communication and hunting}

It is not surprising given the volatiles in spinifex plants that they burn intensely. Bennett (1940s) observed its use as a source of light during night-time corroborees and Latz (1995:293) noted bunches of spinifex leaves used fortuitously as torches. In an interesting mix of cultures, Gudgeon (1963) and Gardam (1957) recorded the use of spinifex fires to light the scenes of Easter and Christmas pageants at the Ernabella Mission in Central Australia.

Accounts and photographs note that individual spinifex plants, particularly resinous species, were also lit to provide short-term immediate warmth (e.g., Baird 1949, Gould 1980:13, Latz 2007:132). As Gould (1980:13) described in the Tikatika area of the Western Desert:

“...there was a slight chill in the air which the men overcome periodically by stopping to ignite a spinifex plant with their firesticks. The resinous plants burst into flame, while the men stood around the fire to get warm. Tjupurula, the oldest man present, always complained about the cold...The men stopped constantly to allow him to 'light up', and since no one attempted to extinguish these fires, we soon had a large area of spinifex burning behind us."

Not surprisingly given its propensity to burn, spinifex was also used to produce smoke signals as a way of communicating (Gould 1980:81, Latz 2007:30) and to aid in the fire making process. When on the move in the Western Desert people kept a firestick glowing by periodically firing a clump of spinifex (Dunlop 1966).

Areas of spinifex were burnt to direct animals so that they could be easily caught and killed (Chewings 1936:40, Finlayson 1933; see Figure 11), flushed into open areas, in the case of ground living animals smoked from their bur-

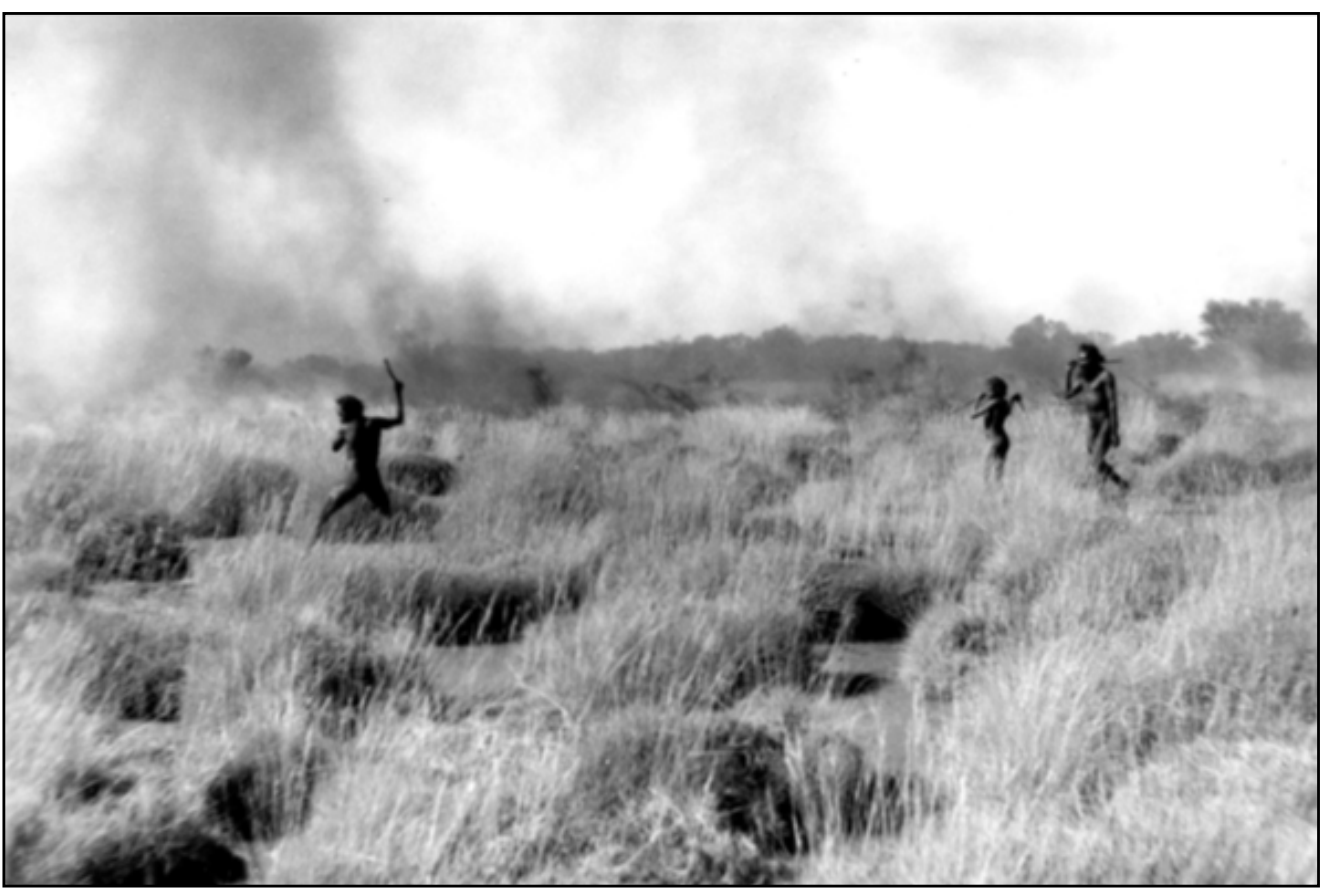

Figure 11. Aboriginal people in the Musgrave Ranges of South Australia using fire in a spinifex grassland to hunt mala. Photograph taken by H. Finlayson in 1933 (Ara Irititja Archive P57646). [Image courtesy of Ara Irititja Archive]. 
rows (Gould 1980:81) or, in rare cases, driven off cliffs (Latz 1995:29). In Central Australia animals could also be easily hunted in the days following a spinifex fire as they could be effortlessly tracked on the cleared ground (Latz 1995:29).

\section{Other miscellaneous uses}

There are several other reported uses of spinifex that do not fall into any of the previous categories, and hence have been collated together here under a 'miscellaneous' heading.

The ubiquitous spinifex of Central Australia did not escape the attention of children, who imaginatively made use of it in a variety of games and play. "Children gather bunches of highly resinous green leaves [from spinifex] which they light at night to produce firework-like sparkers" (Latz 1995:293). Boys used the tall inflorescences from spinifex plants to mount a point from the sharp leaves, which they then used to play a game that involved spearing one another (Hackett 1933). In a similar fashion, Latz (1995:293) reported children using "the long sharp spines to play a rather bloodthirsty game. A drop of blood is placed onto their thigh and any flies attracted to the blood are speared with the spine. The person spearing the most flies in a giv- en time wins!" As illustrated in Lowe with Pike (2009:30), toy axes were also constructed made by folding blades of spinifex grass over each other. Norman Tindale collected wooden kukera play-sticks from Koonibba in near coastal South Australia which were thrown through a pile of spinifex on long prepared lanes of smooth ground (SAM 14189, 14190, 14191, 14192). Similar cigar-shaped wooden pegs with spinifex resin at one end were also collected and recorded as toys by the Berndts at Ooldea (South Australia; BeM 1462.00); it seems likely they were used for a similar purpose as those collected by Tindale. A ball of spinifex gum was also reported used in some type of spinning game, collected by Harry Stockdale in 1900 from northwest Australia (PRM 1900.55.287). Children also used clumps of spinifex (presumably of a soft species!) on which to slide down sand dunes or steep rock faces (Busbridge \& Culhane n.d., Dunbar 1954, Dutschke 1951; Figure 12).

Cane (1987:403, Table V) noted that after collecting Chenopodium rhadinostachyum F.Muell. and Chenopodium inflatum Aellen seeds, spinifex is burned and the resulting ash rubbed together with the chenopod seeds before they are winnowed. This was reportedly undertaken in order to remove the "aromatic flavour of the plant and the herbaceous material surrounding the seeds", a necessary step

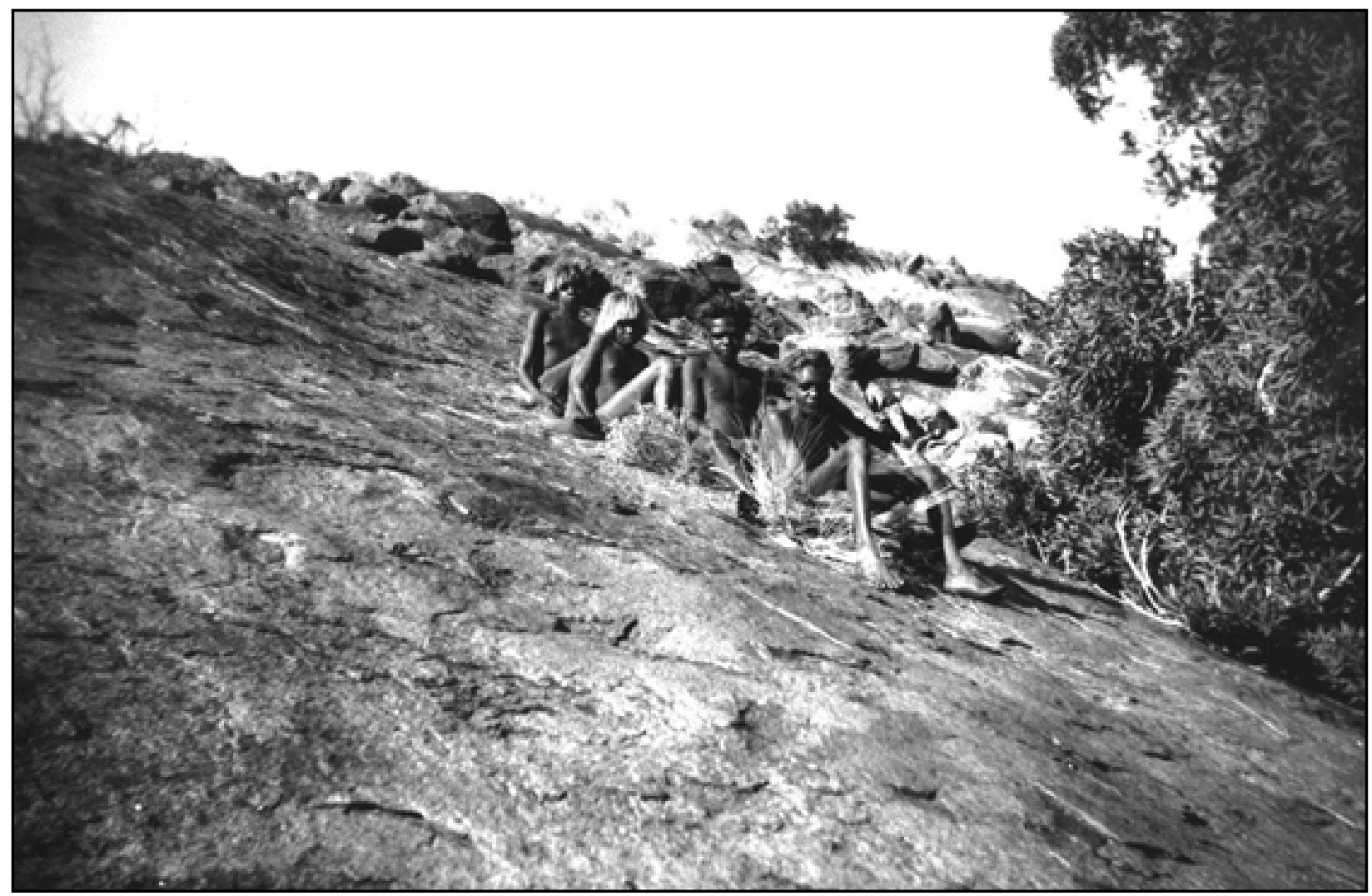

Figure 12. Aboriginal children sliding down a rock-face on a clump of spinifex. Photograph taken by Dutschke near Ernabella, South Australia in 1951 (Ara Irititja Archive P9836). [Image courtesy of Ara Irititja Archive]. 


\section{Pitman \& Wallis - The Point of Spinifex: Aboriginal uses of spinifex grasses in Australia}

before they can be consumed (Cane 1987:403). Whether spinifex was used for this purpose simply because it was the most abundant plant in the area, or whether there was something specific about the chemical composition of the spinifex ash that was vital in the process is unclear.

Spinifex was also reported as having been used to protect items in several ways. In the Great Sandy Desert Cane (1987:400) reported people heaping clumps of spinifex atop piles of seed pods thereby taking advantage of their rigid, tightly packed prickly leaves to deter consumption of the pods by birds and reptiles until required for human use. In another instance, tufts of spinifex were placed in coolamons and were thus used

"to stabilise ... water when it was being carried, preventing it from slopping about and spilling. People maintain that at the same time it kept the water cool even on a hot day" (Lowe with Pike 2009:84).

Despite its oftentimes prickly nature, spinifex was used as padding between an individual's head and object being carried, such as at Ernabella, where Borgelt (1943) filmed men, women and children carrying firewood on their heads, many using tufts of spinifex as padding.
As people responded to the changes in lifestyle brought about by the arrival of non-Indigenous settlers, the uses of spinifex varied accordingly. For instance, photographs in the National Library of Australia and the Australian War Memorial Collection show spinifex being laid in conjunction with wire mesh to stabilise soft roads during construction throughout central and northwest Australia in the first half of the twentieth century (Figure 13). Greenway (1972:73) reported that spinifex (presumably a soft species) served as a good mattress when a canvas was put between it and the occupant, and a photo from Mallapunyah Springs Station, Northern Territory, illustrates its use as a homemade broom (Groom 1952).

\section{Conclusion}

Generally avoided wherever possible by explorers, cursed by the surveyor, used only as a drought reserve by the pastoralist and its recent spread lamented by ecologists, it is difficult to find a favorable reference to spinifex. However, as our research has identified, these ubiquitous and characteristic Australian plants were highly valued for their functionality and versatility by Aboriginal people in the past and remain so today.

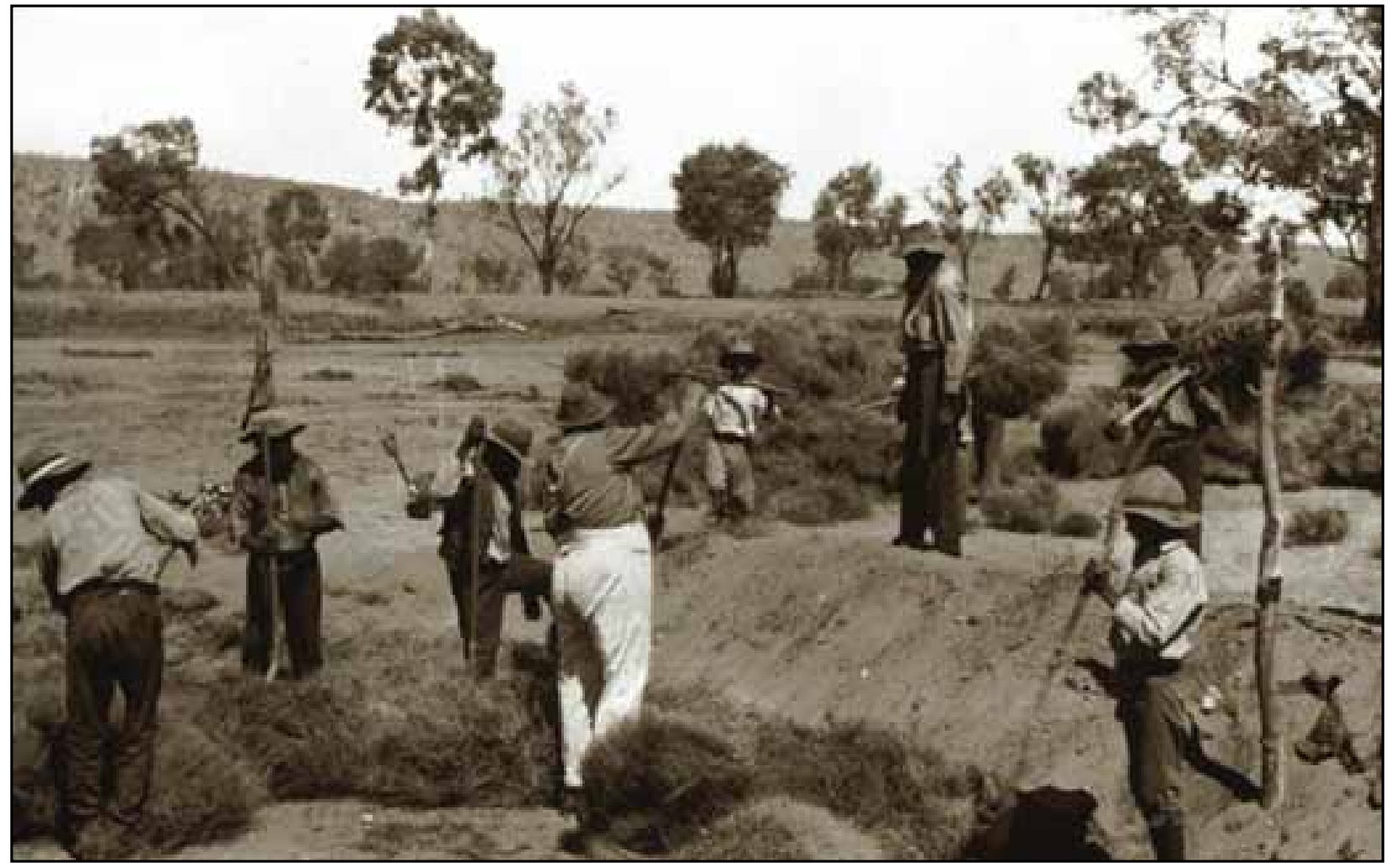

Figure 13. Workers laying spinifex during road construction in Central Australia 1912-1951. Photograph is part of the Australian Inland Mission Collection (nla.pic-an24666817). [Image courtesy of National Library of Australia]. 
We have illustrated that, despite their inherent biases, museum collections and disparate ethnohistoric and ethnographic literature can make a valuable contribution in the study of 'lost' or poorly known Indigenous technologies such as those associated with spinifex. Most commonly known as the source of a resinous adhesive used for hafting composite objects, we have verified a much more extensive repertoire of uses of the processed resin, including for waterproofing, personal ornamentation and the manufacture of churinga boards, beads, figurines, bowls and rings. In some instances, these findings are important as such uses have rarely, if ever, been mentioned in the available ethnographic or ethnohistoric literature. Both spinifex resin and leaves are used in the treatment of a range of medical conditions and ailments that have, as yet, largely escaped the attention of the nonIndigenous community. Further, while greater attention to women's work and the revitalization of craft industries in recent decades has seen knowledge of other Indigenousused fibers become well documented, spinifex fibers have received little attention. However, as we have demonstrated, there is a reasonable evidentiary basis on which to suggest this plant too was traditionally used for such purposes, with bags, nets and string being made from beaten spinifex.

Despite the detailed nature of our assessment, we are aware there are many outstanding areas of research that could be profitably pursued in relation to developing a more nuanced understanding of Indigenous uses of spinifex in Australia. There are Aboriginal Elders in various communities, especially women (who were typically ignored by predominantly male explorers, ethnographers and collectors), who will almost certainly be valuable sources of oral history particularly in relation to ecological knowledge about spinifex. Given our focus on the physical collections of only four Australian museums and others (both in Australia and internationally) with online, searchable databases, it is possible that museums outside of our study may contain additional 'rare' spinifex objects, and hence there may be value in examining other such collections to determine if other categories of spinifex use can be identified. The ARC Spinifex Project exploring the potential of spinifex for use as a sustainable building material is already investigating the physico-chemical properties of select spinifex resins (e.g., Gamage et al. 2012, Mondal et al. 2012), physical properties of spinifex fibers (Flutter 2009, Gamage et al. 2012) and ecological aspects of spinifex (e.g., Neave 2010); however there is considerable scope for further research in these areas, especially in relation to variability in resin production and properties among different resinous species.

In summary, we are confident that this report will be of interest to Indigenous community members who may no longer be fully cognisant of the diverse array of uses of spinifex and have already begun the process of disseminating our findings to communities; further progress will be made in this area in coming years as a collaboration between the authors and the South Australian Museum and Flinders University Art Museum to develop a travelling exhibition about spinifex is underway. Given the widespread distribution and dominance of spinifex in the Australian landscape, we encourage increased levels of community-based, cooperative research drawing on traditional Indigenous knowledge such as suggested above, and we hope this work will also alert researchers and land managers to the otherwise often neglected cultural importance of this plant.

\section{Acknowledgements}

Parts of this research were undertaken by Pitman as part of her honours thesis at Flinders University. The broader spinifex project, led by Prof. Paul Memmott, has been funded by Australian Research Council (DP0877161). The authors would like to thank Ruby Saltmere, Shirley MacNamara, Hazel Windsor, Colin Saltmere and Sally Sheldon for their support and advice during fieldwork in northwest Queensland. Thank you to Paul Memmott, Alice Gorman, Bob Tonkinson, Chris Clarkson, Darren Martin and Peter Bindon for discussions about uses of spinifex. We are especially grateful to museum and archive staff including Lindy Allen, Alice Beale, Brian Coghill, Louise Crossley, John Dallwitz, Tara Dodd, Lea Gardam, Mikhala Harkins, Helen Hooper, Tony Kanellos, Kirsty Lewis, Tara Lewis, Meg Lloyd, Barbara Matters, Melanie Raberts, Moya Smith, Gary Toone and Keryn Walshe for their assistance in facilitating access to collections during the course of this research.

\section{Literature Cited}

Aboriginal Communities of the Northern Territory. 1993. Traditional Aboriginal Medicines in the Northern Territory of Australia. Conservation Commission of the Northern Territory of Australia, Darwin, Australia.

Aiston, G. 1929. Method of mounting stone tools on koondi: Tribes east and north-east of Lake Eyre. Papers and Proceedings of the Royal Society of Tasmania March:44-46.

Akerman, K. 1978. Notes on the Kimberley stone-tipped spear focusing on the point hafting mechanism. Mankind 11(4):486-489.

Akerman, K. with J. Stanton. 1994. Riji and Jakuli: Kimberley Pearl Shell in Aboriginal Australia. Northern Territory Museum of Arts and Sciences Monograph No. 4. Northern Territory Museum of Arts and Sciences, Darwin, Australia. 


\section{Pitman \& Wallis - The Point of Spinifex: Aboriginal uses of spinifex grasses in Australia}

Anonymous. 1887. Latest telegrams-Adelaide March 9th, Colonial and Intercolonial. The Northern Territory Times and Gazette Saturday 12 March 1887:3.

Baird, M. 1949. Women warming by a spinifex fire, Ernabella. Photograph (p4839) in the Frank and Mary Bennett Collection, Ara Irititja Archive, Marleston, South Austalia.

Basedow, H. 1925. The Australian Aboriginal. Preece, Adelaide, South Australia.

Bates, D. 1985. The Native Tribes of Western Australia. National Library of Australia, Canberra.

Belk, R.W. \& M. Wallendorf. 1994. Of mice and men: Gender identity in collecting. Pp. 240-253 in Interpreting Objects and Collections. Edited by S.M. Pearce. Routledge, London.

Bell, D. 1983. Daughters of the Dreaming. McPhee Gribble/George Allen and Unwin, North Sydney, New South Wales.

Bennett, F. 1940s. Musgrave and Mann Ranges. Unpublished notes accompanying photographic album (d241713, Frank and Mary Bennett Collection, Ara Irititja Archive, Marleston, South Australia.

Berndt, R. \& C. Berndt. 1943. A preliminary report on field work in the Ooldea region, western South Australia (continued). Oceania 14:124-158.

Berndt, R. \& C. Berndt. 1945. A preliminary report on field work in the Ooldea region, western South Australia (continued). Oceania 15:154-165.

Bindon, P. 1996. Useful Bush Plants. Western Australian Museum, Perth, Western Australia.

Bindon, P. [A.R. Peile]. 1997. Editor of Body and Soul: An Aboriginal view. Hesperian Press, Victoria Park, Western Australia.

Binford, L. 1984. An Alyawara day: flour, spinifex gum, and shifting perspectives. Journal of Anthropological Research 40(1):157-182.

Blee, A.J., K. Walshe, A. Pring, J.S. Quinton \& C.E. Lenehan. 2010. Towards the identification of plant and animal binders on Australian stone knives. Talanta 82:745-750.

Borgelt, L. 1943. August, Ernabella. Film, Lutheran Archives (Borgelt) (m1021-3), Ara Irititja Archive, Marleston, South Australia.

Bowden, B.F. \& B. Reynolds. 1982. The chromatographic analysis of ethnographic resins. Newsletter of the Australian Institute of Aboriginal Studies 17:41-43.
Brokensha, P. 1975. The Pitjantjatjara and Their Crafts. Aboriginal Arts Board and Australia Council, Sydney, New South Wales.

Burbidge, N. 1946. Morphology and anatomy of the Western Australian species of Triodia R.Br. II. Internal anatomy of leaves. Transactions of the Royal Society of South Australia 70:221-234.

Busbridge, D. \& B. Culhane. n.d. Amaraltja (near Amata). Unpublished photograph in the Don Busbridge and Betty Culhane Collection (p22905), Ara Irititja Archive, Marleston, South Australia.

Campbell, T.D. 1963. Palya - Prepared Spinifex Gum. Film. University of Adelaide Board for Anthropological Research, Adelaide, South Australia.

Cane, S. 1987. Australian Aboriginal subsistence in the Western Desert. Human Ecology 15(4):391-434.

Cane, S. 2002. Pila Nguru: The spinifex people. Fremantle Arts Centre Press, North Fremantle, Western Australia.

Carnegie, D.W. 1898. Spinifex and Sand: A narrative journal of five years' pioneering and exploration in Western Australia. C. Arthur Pearson, London.

Chewings, C. 1936. Back in the Stone Age: The natives of Central Australia. Angus and Robertson, Sydney, New South Wales.

Clarke, P.A. 2007. Aboriginal People and Their Plants. Rosenberg Publishing, Dural, New South Wales.

Cleland, J.B. 1966. The ecology of the Aboriginal in South and Central Australia. Pp. 111-158 in Aboriginal Man in South and Central Australia (Part 1). Edited by B.C. Cotton. The Board for Anthropological Research, University of Adelaide, Adelaide, South Australia.

Clement, E. \& J.D.E. Schmeltz. 1903. Ethnographical notes on the Western-Australian Aborigines. Internationales Archiv Fur Ethnographie 16:1-29.

Conkey, M.W. \& J.M. Gero. 1991. Tensions, pluralities, and engendering archaeology: An introduction to women in prehistory. Pp. 3-30 in Engendering Archaeology: Women and Prehistory. Edited by M.W. Conkey and J.M. Gero. Basil Blackwell, Oxford, United Kingdom.

Cooper, C. 1989. Aboriginal and Torres Strait Islander Collections in Overseas Museums. Aboriginal Studies Press, Canberra.

Cribb, A.B. \& J.W. Cribb. 1982. Useful Wild Plants in Australia. Fontana Books, Sydney, New South Wales. 
Cribb, A.B. \& J.W. Cribb. 1988. Wild Medicine in Australia. Collins, Sydney., New South Wales

Cribb, J.W. 1985. Australia's medicinal plants. Medical Journal of Australia 143:574-577.

De Graaf, M. 1967. The manufacture of spinifex gum by desert Aborigines. Western Australia Naturalist 10(5):116119.

Dunbar, L. 1954. Children sliding down sand-hill on clumps of spinifex, Wamikata. Photograph in the Lex and Jessie Dunbar Collection (p17864), Ara Irititja Archive, Marleston, South Austalia.

Dunlop, I. 1966. People of the Australian Western Desert. Parts 2, 5, 7 and 13. Film produced by the Australian Institute of Aboriginal Studies, Sydney, New South Wales.

Dutschke, M. 1951 Children sliding down a rock-face on clumps of spinifex, February 1951, Ernabella. Photograph in the Melvin Dutschke Collection (p9836), Ara Irititja Archive, Marleston, South Austalia.

Dymock, J. 1979. A small sample of Wanyi medicine. Journal of the Anthropological Society of South Australia 17(5):41-45.

Edwards, D.A. \& J.F. O'Connell. 1995. Broad spectrum diets in arid Australia. Antiquity 69(265):769-783.

Edwards, R. \& J. Stewart. 1980. Editors of Preserving Indigenous Cultures: A new role for museums. Australian Government Publishing Service, Canberra.

Elkin, A.P. 1964. The Australian Aborigines: How to understand them. Angus and Robertson, Sydney, New South Wales.

Finlayson, H.H. 1933. Using fire to burn spinifex, and line up of hunters with sticks hunting malu [sic]. Photograph in the H.H. Finlayson Collection (p57646), Ara Iritija Archive, Marleston, South Austalia.

Flinders, C.E. 1920-1936. Aboriginal men and women catching fish using spinifex for net, Kimberley. Photograph in the Charles Edward Collection of Kimberly photographs, ca1920-1936 (BA1459/170), State Library of Western Australia, Perth, Western Australia.

Flutter, N. 2009. Spinifex grass as a source of cellulose fibres and resin matrix for biocomposite materials. Unpublished Master of Architecture thesis, School of Architecture, The University of Queensland, Brisbane, Queensland.
Fullagar, R. \& J. Field. 1997. Pleistocene seed-grinding implements from the Australian arid zone. Antiquity 71:300-307.

Gamage, H.K., S. Mondal, L.A. Wallis, P. Memmott, D. Martin, B.R. Wright \& S. Schmidt. 2012. Indigenous and modern biomaterials derived from Triodia ('spinifex') grasslands in Australia. Australian Journal of Botany 60:114-127.

Gardam, F. 1957. Ernabella. Photograph in the Faye and Noel Gardam Collection (p20231), Ara Irititja Archive, Marleston, South Austalia.

Goddard, C. \& A. Kalotas. 1988. Editors of Punu Yankunytjatjara Plant Use. Traditional Methods of Preparing Foods, Medicines, Utensils and Weapons from Native Plants. Angus and Robertson, North Ryde, New South Wales.

Gorecki, P., M. Grant, S. O'Connor \& P. Veth. 1997. The morphology, function and antiquity of Australian grinding implements. Archaeology in Oceania 32(2):141-150.

Gould, R.A. 1970. Spears and Spear-Throwers of the Western Desert Aborigines of Australia. American Museum Novitates 2403. American Museum of Natural History, New York, New York.

Gould, R.A. 1980. Living Archaeology. Cambridge University Press, New York, New York.

Grant, M. \& P. Gorecki. 1996. Aboriginal and Historic Cultural Heritage Impact Assessment Study, Barkly Highway. Unpublished report to Queensland Transport North West Region, Sunnybank, Queensland.

Greenway, J. 1972. Down Among the Wild Men: The Narrative Journal of Fifteen Years Pursuing the Old Stone Age Aborigines of Australia's Western Desert. Little, Brown and Company, Boston, Massachusetts.

Gregory, A.C. \& T.F. Gregory. 1884. Journals of Australian Explorations. Government Printer, Brisbane, Queensland.

Griffin, G.F. 1984. Hummock grasslands. Pp. 271-284 in Management of Australia's Rangelands. Edited by G.N. Harrington, A.D. Wilson \& M.D. Young. Commonwealth Scientific and Industrial Research Organization Publishing, Melbourne, Victoria.

Griffiths, T. 1996. Hunters and Collectors: The antiquarian imagination in Australia. Cambridge University Press, Cambridge, United Kingdom.

Groom, A. 1952. Kate Darcy of Mallapunyah and a home made spinifex broom, Northern Territory. Photograph in 


\section{Pitman \& Wallis - The Point of Spinifex: Aboriginal uses of spinifex grasses 129 in Australia}

the Arthur Groom collection (nla.pic-an23165299), National Library of Australia, Canberra.

Gudgeon, S. 1963. Spinifex windbreak being used for a nativity scene, Ernabella, December 1963. Photograph in the Shirley Gudgeon (Hill) Collection (p6522), Ara Irititja Archive, Marleston, South Austalia.

Hackett, C.J. 1933. Boys playing spinifex spear game, $19^{\text {th }}$ July 1933, Mann Ranges. South Australian Museum (Hackett) Collection (AA122 'A Letter about an Unknown World', p. 60-61, neg. J/A/33/45-J/A/33/47) (p36326p36329), Ara Irititja Archive, Marleston, South Austalia.

Jacobs, S.W.L. 2004. The tribe Triodieae (Chloridoideae: Gramineae). Telopea 10(3):701-703.

Jessop, J., F.M. James \& G.R.M. Dashorst. 2006. Grasses of South Australia: An illustrated guide to the native and naturalised species. Wakefield Press, Adelaide, South Australia.

Jones, P.G. 1996. 'A Box of Native Things' : Ethnographic Collectors and the South Australian Museum, 1830s1930s. Ph.D. thesis, Department of History, University of Adelaide, Adelaide, South Australia.

Jones, P. \& P. Sutton. 1986. Art and Land: Aboriginal sculpture of the Lake Eyre region. South Australian Museum in association with Wakefield Press, Adelaide, South Australia.

Juluwarlu Aboriginal Corporation. n.d. Wanggalili: Yindjibarndi and Ngarluma plants. Juluwarlu Aboriginal Corporation, Roebourne, Western Australia.

Kaberry, P. 1939. Aboriginal Woman: Sacred and profane. George Routledge and Sons, London.

Kelleher, P. \& P. Memmott. 1997. Kimberley settlers (Western Australia, N). P. 1076 in Encyclopaedia of Vernacular Architecture of the World. Edited by P. Oliver. Cambridge University Press, Cambridge, United Kingdom.

Langenheim, J.H. 2003. Plant Resins: Chemistry, evolution, ecology and ethnobotany. Timber Press, Cambridge.

Latz, P. 1995. Bushfires and Bushtucker: Aboriginal plant use in Central Australia. IAD Press, Alice Springs, Northern Territory.

Latz, P.K. 2007. The Flaming Desert: Arid Australia - A fire shaped landscape. Peter Latz, Alice Springs, Northern Territory.

Lazarides, M. 1997. A revision of Triodia including Pletrachne (Poaceae, Eragrostideaec, Triodiinae). Australian Systematic Botany 10:381-489.
Levy, J.E. 2007. Gender, heterarchy and hierarchy. Pp. 189-216 in Women in Antiquity: Theoretical approaches to gender and archaeology. Edited by S.M. Nelson. Altamira Press, Plymouth, Massachusetts.

Lockhart Morton, W. 1884. Native fibre for woolpacks. The Argus (Melbourne). Thursday 20 March:9.

Long, J.P.M. 1971. Arid region Aborigines: The Pintubi. Pp. 262-270 in Aboriginal Man and Environment in Australia. Edited by D.J. Mulvaney \& J. Golson. Australian National University Press, Canberra.

Lottery West. n.d. Grants: Establishing a spinifex enterprise. www.lotterywest.wa.gov.au/grants/grant-stories/1899. Viewed 19 May 2010.

Lowe, P. with J. Pike. 2009. You Call it Desert - We Used to Live There. Margabala Books, Broome, Western Australia.

Maiden, J.H. 1889. The Useful Native Plants of Australia. Alexander Brothers, Mentone, Victoria.

McBryde, I. 1987. Goods from another country: Exchange networks and the people of the Lake Eyre Basin. Pp. 25373 in Australians: A Historical Library Australians to 1788. Edited by D.J. Mulvaney \& J.P. White. Fairfax, Syme \& Weldon Associates, Broadway, New South Wales.

McGrath, A. 1990. The white man's looking glass: Aboriginal colonial gender relations at Port Jackson. Australian Historical Studies 24(95):189-206.

Meggitt, M.J. 1962. Desert People: A study of the Walbiri Aborigines of Central Australia. The University of Chicago Press, London.

Memmott, P. \& C. Go-Sam. 2007. Spinifex houses of the Western Desert. Pp. 208-231 in Gunyah, Goondie + Wurley: The Aboriginal architecture of Australia. Edited by P. Memmott. University of Queensland Press, Brisbane, Queensland.

Mondal, S., P. Memmott, L. Wallis \& D. Martin. 2012. Physico-thermal properties of Triodia resin bio-polymer. Materials Chemistry and Physics 133(2-3):692-699.

Moore, P. 2005. A Guide to Plants of Inland Australia. Reed New Holland, Sydney, New South Wales.

Moses, R. 1986. Djuru story: The first white man comes to Nicholson River. Translated by T. Tasaku. Pp. 41-46 in This is What Happened. Edited by L. Hercus \& P. Sutton. Australian Institute of Aboriginal and Torres Strait Islander Studies, Canberra. 
Mountford, C.P. \& A. Harvey. 1938. A survey of Australian Aboriginal pearl and baler shell ornaments. Records of the South Australian Museum 6(2):115-135.

Neave, G.B. 2010. Regeneration of spinifex (Triodia spp.) grasslands after burning or harvesting. B.Sc. (Honors) thesis, School of Biological Sciences, University of Queensland, Brisbane, Queensland.

Nicholls, A. 2005. The West: contemporary basket making in Western and Central Australia. Pp. 34-39 in Woven Forms: Contemporary basket making in Australia. Edited by B. Parkes. Australian Centre for Craft and Design, Sydney, New South Wales.

Nobbs, C.W. 1985. The legend of the Muramura Darana and his Milis at Killalpaninna. Journal of the Anthropological Society of South Australia 23(8):16-25.

Noone, H.V.V. 1949. Some implements of the Australian Aborigines with European parallels. Man 49:111-114.

O'Connell, J.F. \& K. Hawkes. 1981. Alyawara plant use and optimal foraging theory. Pp. 99-125 in Hunter-Gatherer Foraging Strategies. Edited by B. Winterhalder \& E.A. Smith. University of Chicago, Chicago, Illinois.

O'Connell, J.F. \& K. Hawkes. 1981. Alyawara plant use and optimal foraging theory. Pp 99-125 in Hunter-Gatherer Foraging Strategies. Edited by B. Winterhalder \& E.A. Smith. University of Chicago Press, Chicago, Illinois.

O'Connell, J.F., P.K. Latz \& P. Barnett. 1983. Traditional and modern plant use among the Alyawara of central Australia. Economic Botany 37(1):80-109.

Parkes, B. 2005. Editor of Woven Forms: Contemporary basket making in Australia. Object: Australian Centre for Craft and Design, Sydney, New South Wales.

Pate, D. 1986. The effects of drought on Ngatatjara plant use: an evaluation of optimal foraging theory. Human Ecology 14(1):95-115.

Peterson, N., L. Allen \& L. Hamby. 2008. Editors of The Makers and Making of Indigenous Australian Museum Collections. Melbourne University Press, Melbourne, Victoria.

Pitman, H. 2010. Pointless Spinifex? An investigation of Indigenous use of spinifex throughout Australia. B.Arch. (Honors) thesis, Department of Archaeology, Flinders University of South Australia, Adelaide, South Australia.

Roth, W.E. 1897. Ethnological Studies among the NorthWest-Central Queensland Aborigines. Government Printer, Brisbane, Queensland.
Roth, W.E. 1904. Domestic Implements, Arts and Manufactures. North Queensland Ethnography Bulletin 7. Queensland Government Printer, Brisbane, Queensland.

Satterthwait, L. 2008. Collections as artefacts: The making and thinking of anthropological museum collections. Pp. 29-60 in The Makers and Making of Indigenous Australian Museum Collections. Edited by N. Peterson, L. Allen \& L. Hamby. Melbourne University Press, Melbourne, Victoria.

Schulze, L. 1891. The Aborigines of the Upper and Middle Finke River: Their habitats and customs, with introductory notes on the physical and natural history features of the country. Transactions of the Royal Society of South Australia 14:210-246.

Sheridan, G. 1979. Tulas and Triodia: A multidisciplinary investigation of the mechanics and antecedents of the koondi tula and their implications for prehistory. M.A. (Qualifying) thesis, Department of Prehistory and Anthropology, School of General Studies, The Australian National University, Canberra.

Smith, N.M. 1991. Ethnographic field notes from the Northern Territory, Australia. Journal of the Adelaide Botanic Gardens 14(1):1-65.

Spencer, B. 1896. Part 4: Anthropology. Pp. 1-200 in Report of the Work of the Horn Scientific Expedition to Central Australia. Edited by B. Spencer. Melville, Mullen \& Slade, Melbourne, Victoria.

Spencer, B. \& B. Gillen. 1899 [1938]. The Native Tribes of Central Australia. Macmillan and Company, London.

Spencer, B. \& F.J. Gillen. 1904 [1969]. The Northern Tribes of Central Australia. 2nd edition. Anthropological Publications, Oosterhout, The Netherlands.

Thomas, N.W. 1906. The Native Races of The British Empire: Natives of Australia. Archibald Constable and Company, London.

Thomson, D.F. 1964. Some wood and stone implements of the Bindibu tribe of central Western Australia. Proceedings of the Prehistoric Society 30:400-422.

Tindale, N.B. 1965. Stone implement making among the Nakako, Ngadadjara and Pitjandjara of the Great Western Desert. Records of the South Australian Museum 15:131164.

Tindale, N.B. 1977. Adaptive significance of the Panara or grass seed culture of Australia. Pp. 345-349 in Stone Tools as Cultural Markers: Change, Evolution and Complexity. Edited by R.S.V. Wright. Australian Institute of Aboriginal Studies, Canberra. 


\section{Pitman \& Wallis - The Point of Spinifex: Aboriginal uses of spinifex grasses 131 in Australia}

Vaarzon-Morel, P. 1995. Editor of Warlpiri Karnta Karnta Kurlangu Yimi. Warlpiri Women's Voices - Our Lives Our History. IAD Press, Alice Springs, Northern Territory.

Walsh, F.J. 1987. Patterns of Plant Resource Use by Martujarra Aborigines. M.Sc. (Preliminary) thesis, University of Western Australia, Perth, Western Australia.

Watson, L. \& M.J. Dallwitz. 1992. The Grass Genera of the World. CAB International, Wallingford, Oxfordshire, United Kingdom.

Webb, L.J. 1959. The use of plant medicines and poisons by Australian Aborigines. Mankind 7:137-146.

Weedman, K. 2007. Gender and ethnoarchaeology. Pp. 217-264 in Women in Antiquity: Theoretical approaches to gender and archaeology. Edited by S.M. Nelson. Altamira Press, Plymouth, Massachusetts.
Wells, G.B. 1999. Biology and restoration ecology of spinifex Grasses (Plectrachne and Triodia spp.) with special reference to the Argyle Diamond Mines (Western Australia). Ph.D. thesis, University of Western Australia, Perth, Western Australia.

Wightman, G.M., D. Dixon, L. Williams \& I. Dalywaters. 1992. Mudburra ethnobotany: Aboriginal plant use from Kulumindini (Elliot), Northern Australia. Northern Territory Botanical Bulletin 14:1-44.

Wightman, G.M., D. Jackson \& L. Williams. 1991. Alawa ethnobotany Aboriginal plant use from Minyerri, Northern Territory. Northern Territory Botanical Bulletin 11:1-36.

Wright, B.J. 1970. Notes and Transcripts on Some Plants of the Pilbara and their Traditional use by the Aborigines. Manuscript held on file at the Australian Institute of Aboriginal and Torres Strait Islander Studies (PMS 2079), Canberra. 
